\title{
Reservoir descriptions of the Kömürlü and Penek Formations near Erzurum, East Anatolia, Turkey
}

\author{
Aylin Geçer ${ }^{1}$ - Aynur Büyükutku² ${ }^{2}$ - Fatih Gültekin ${ }^{2}$
}

Received: 10 August 2018 / Accepted: 19 March 2019 / Published online: 25 March 2019

(c) The Author(s) 2019

\begin{abstract}
In the work presented here, core and cutting samples from a single well were studied with the aim of understanding the diagenesis and reservoir properties of the Kömürlü and Penek Formation sandstones in the Aşkale sub-basin in East Anatolia. Based on petrological and hydrocarbon saturation analyses [attenuated total reflectance-Fourier-transform infrared spectroscopy] of the samples, we discuss the relationships between diagenetic alterations and reservoir quality. The diagenetic alterations include quartz, feldspar overgrowth, calcite, smectite, chlorite, mixed-layer illite-smectite, mixed-layer chloritesmectite, illite, kaolinite, and pyrite. After the diagenetic mineral phases formed, secondary porosity formed via dissolution of late carbonate cement in these sandstones. Diagenesis in the Kömürlü and Penek Formation sandstones commonly destroyed much of the original intergranular porosity, dissolved grains, and produced clay-filled pores. The pore throats typically range in size from 1 to $5 \mu \mathrm{m}$ and represent only a small portion of the total porosity. This study is the first attempt to make petrophysical data available from the well logs of the reservoir sandstones (Kömürlü and Penek Formations) in the Aşkale sub-basin of the East Anatolia Basin. The results of this study will clarify the characterization of the reservoir sandstones.
\end{abstract}

Keywords Reservoir · Diagenesis $\cdot$ Hydrocarbon $\cdot$ Well logs $\cdot$ ATR-FTIR

\section{Introduction}

Several previous studies have addressed the petroleum potential of the Aşkale sub-basin (Kurtman and Akkus 1971; Şahintürk 1992; Şahintürk et al. 1997; Büyükutku 2002; Tekin 2002; Büyükutku and Şahintürk 2005, 2006). In the study area to date, no significant deposits of hydrocarbons have been discovered in the Kömürlü and Penek Formation sandstones, despite speculation that hydrocarbons may be present (Büyükutku and Şahintürk 2006). We report that

Electronic supplementary material The online version of this article (https://doi.org/10.1007/s13202-019-0645-6) contains supplementary material, which is available to authorized users.

Aynur Büyükutku

mxwb2448@yahoo.com

Aylin Geçer

plnck1734@yahoo.com

1 Department of Chemical Engineering, Ankara University Faculty of Engineering, 06100 Beşevler, Ankara, Turkey

2 Department of Geological Engineering, Ankara University Faculty of Engineering, 06830 Gölbaş1, Ankara, Turkey these Kömürlü and Penek Formation sandstones have poor reservoir properties.

The rock properties of shale sourced from the Kömürlü and Penek Formations were studied by Tekin (2002), and the kerogene types were found to be I-II.

In the work presented here, core and cutting samples from a single well (Fig. 1) were studied with the aim of understanding the diagenesis and reservoir properties of the Kömürlü and Penek Formations.

The scope of our study was to (1) determine the mineralogy, morphology, and elemental composition of the Kömürlü and Penek Formation sandstones; (2) investigate the presence of hydrocarbon in these sandstones; (3) define the petrophysical properties (water saturation, porosity, and permeability) of these sandstone reservoirs; (4) determine the pore throat range in diameter; (5) discuss the diagenetic alteration, dissolution, porosity, and effect on reservoir quality; and (6) reveal the effect of clay minerals on the Kömürlü and Penek Formation sandstones. 

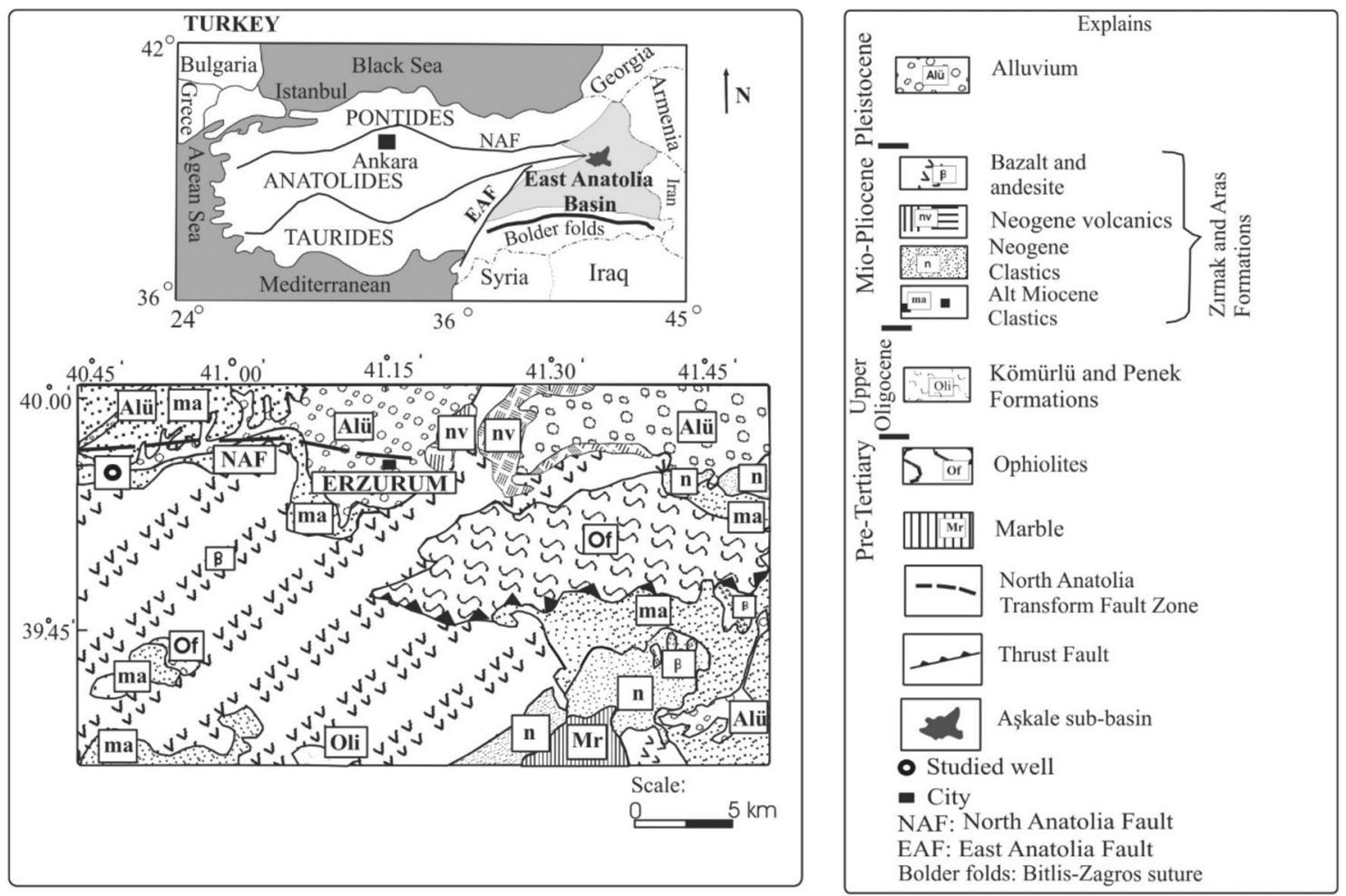

Fig. 1 Location map of Aşkale sub-basin, East Anatolia, Turkey (modified from Şahintürk et al. 1997)

\section{Geological history and setting of the Aşkale sub-basin and local stratigraphy}

The East Anatolia sedimentary basins (approximately $6000 \mathrm{~m}$ in thickness) were shaped during the upper Miocene and are related by faults and ophiolitic melange (Şengör 1980). The basins extend in the $\mathrm{E}-\mathrm{W}$ direction as a result of N-S directional compressions (McKenzie 1976; Tc Tchalenko 1977) and are subdivided into seven sub-basins (Şahintürk et al. 1998; Büyükutku and Şahintürk 2006).

The study area was located west of Erzurum city (Eastern Turkey). The pre-Tertiary sedimentary, magmatic, and metamorphic rocks in this area were treated as the basement (Fig. 1) and are thrusted (Tarhan et al. 1992; Şahintürk et al. 1997). In the study area, the Tertiary layer reaches approximately $2450 \mathrm{~m}$ in thickness (Büyükutku and Şahintürk 2006).

The evolution of the Oligo-Miocene sediments in the Aşkale sub-basin is summarized as follows: the Penek Formation was deposited under very shallow marine-transitional conditions during the upper Oligocene (Büyükutku and Şahintürk 2005). The Kömürlü Formation (1450 m thick) was deposited under shallow marine lagoonal-transitional conditions in the Aşkale sub-basin (Büyükutku and Şahintürk 2005).
A generalized stratigraphic section of the Asskale subbasin and core log of the studied well is presented in Fig. 2a, b. The properties of clastic units present in the sandstone reservoir are as follows. The Penek Formation is approximately $1200 \mathrm{~m}$ thick and unconformably overlies the pre-Tertiary sediments (Sungurlu 1971; Şahintürk et al. 1980; Tekin et al. 2000). The Penek Formation consists of medium- to coarse-grained sandstones broadly arranged into white, red and green areas intercalated with shales and conglomerates. In the studied well, this unit is approximately $600 \mathrm{~m}$ thick and is gradational to the overlying Kömürlü Formation.

The Kömürlü Formation, first described by Sungurlu (1971), mainly contains fine- to medium-grained sandstones poorly sorted into white, red, and green areas intercalated with shale layers. The Kömürlü Formation is approximately $700 \mathrm{~m}$ thick in the studied well and unconformably overlies the Penek Formation. This unit is mainly composed of clastic lithologies such as conglomerates, sandstones, shales, marls, carbonates, basalts, and tuff. The Zirnak Formation (İlker 1966) is approximately $2500-3000 \mathrm{~m}$ thick and represents lacustrine and transitional depositional conditions (Şahintürk and Kasar 1980). The Aras Formation (Sungurlu 1971) unconformably overlies the Zirnak Formation. The Aras Formation was formed under terrestrial depositional conditions and is mainly composed of marls and tuffs. This 
(a)

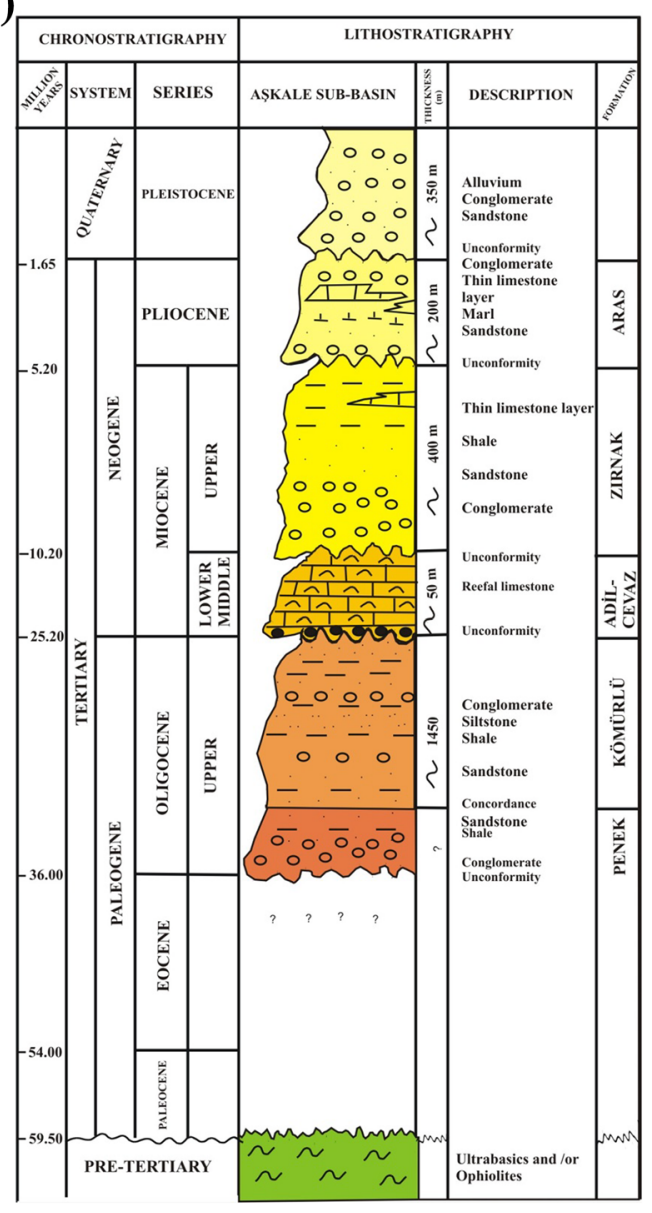

(b)

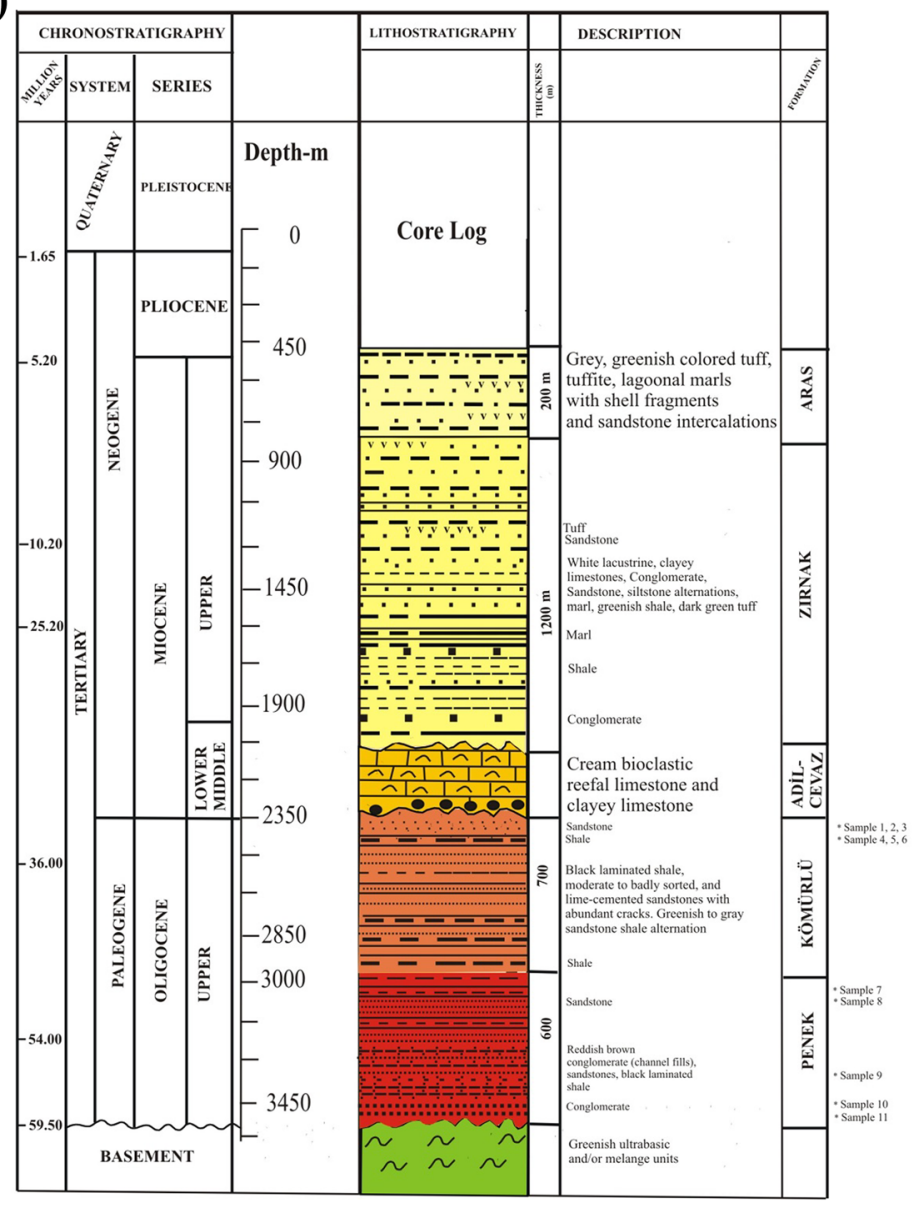

Fig. 2 a Stratigraphic columns for the sedimentaries of Aşkale sub-basin, East Anatolia, Turkey [modified after Aksu (1988) and Şahintürk (1992)]. b Core log of the study well in the Aşkale sub-basin

study focused on the upper Oligocene sandstones of the Kömürlü and Penek Formations.

\section{Materials and methods}

Eight cores, 70 sandstone cutting samples, and wire-line logs from a single well in the Aşkale sub-basin of East Anatolia were studied.

The mineral composition of the studied samples was determined by X-ray powder diffraction (XRD) (PW-1730, Philips, Eindoven, The Netherlands) at the TPAO (Turkish Petroleum Corporation, Turkey). All samples were ground gently for $5 \mathrm{~min}$ in a porcelain ball mill prior to measurement. Mineralogical analyses of the samples were performed on randomly oriented samples (total fraction) and on the clay $(<2 \mu \mathrm{m})$ fraction. The clay fraction was obtained by gravitational sedimentation of the samples. XRD analyses were performed on eight oriented samples of clay particles that were air-dried, ethylene glycol saturated, and heated to $550{ }^{\circ} \mathrm{C}$. The microstructural properties of these samples were determined in detail by scanning electron microscopy (SEM) (JSM-840A, Jeol Europe BV, Nieuw-Vennep, The Netherlands) equipped with an energy-dispersive spectroscopy (EDS) analyser (TN-5502, Trocor, The Netherlands). SEM-EDS analyses were performed on seven core samples in the TPAO laboratories.

In other research areas, previous reports have mentioned that organic matter is present in shales and that FTIR spectroscopy can be used to determine the presence of hydrocarbons and the types of minerals in the sample (Shoval and Nathan 2011; Alstadt et al. 2012). Additionally, the characterization of clay minerals by FTIR spectroscopy (Awaja and Bhargava 2006; Breen et al. 2008; Herron et al. 2014) is important for petroleum reservoir studies due to the negative effect of clay minerals on hydrocarbon production in sandstone reservoirs. In this study, the ATR-FTIR method, which is more economical than Rock Eval analysis, was used for the first time on samples from the Asskale sub-basin. The ATR technique was selected to combat significant problems 
of infrared analyses, such as sample preparation and spectral reproducibility (Adamu 2010; Udvardi et al. 2014).

An FTIR spectrometer (Nicolet Magna 750, Nicolet Instrument Corporation, Markham, Ontario, Canada) was used to determine the chemical origin of the organic samples, organic structure, and authigenic clay type for shales rich in organic matter. FTIR analyses were performed on eight core samples at the University of Castilla-La Mancha laboratories in Spain. For each sample, 128 scans were recorded with a resolution of $4 / \mathrm{cm}$. ATR spectra were obtained using a MIRacleTM and a single-reflection horizontal ATR accessory (PIKE technologies) equipped with a ZnSe crystal. The powdered samples were pressed with a compression clamp.

Log interpretation was carried out on a single well located in the Aşkale sub-basin of the East Anatolia Basin to determine the reservoir properties of the Kömürlü and Penek Formations. Well log data from the deep parts of the well were used to determine some petrophysical characteristics, namely porosity, permeability, and water saturation, of the reservoir sandstones. Well log data were obtained from gamma ray (GR), sonic (DT), resistivity (LLS, LLD), density (RHOB), and neutron logs (NPHI). This study is the first attempt to make petrophysical data available from well logs of the reservoir sandstones (Kömürlü and Penek Formations) in the Asskale sub-basin of the East Anatolia Basin. The results of this study will also improve the characterization of the reservoir sandstones.

Additionally, the porosity values of the Kömürlü and Penek Formation sandstones were determined with thin-section data, and DT, NPHI and RHOB (total porosity) log data from the studied well according to Schlumberger (1986). Clay percentages were determined by GR log. Porosity and permeability analyses of seven core samples in the Kömürlü Formation sandstones were conducted to interpret reservoir quality. Porosity was measured using a helium gas expansion porosimeter, and permeability was measured using a Temco $\mathrm{RCH}$ series model permeameter at TPAO.

\section{Results}

\section{Framework petrology}

Thin sections were prepared from 35 sandstone core and clastic samples taken from depths of approximately 2360-3570 m from a single well in the Aşkale sub-basin.

Petrographic analyses of the Penek and Kömürlü Formation sandstones were carried out from thin sections using optical microscopy (Table 1; Figs. 3, 4). The Kömürlü and Penek Formation sandstones are classified as litharenites (McBride 1963). Litharenitic sandstones include metamorphic, sedimentary, and magmatic rock fragments in the sub-basin.

\section{Diagenetic phases}

The most important diagenetic phases of the Kömürlü and Penek Formation sandstones are quartz, feldspar overgrowth, calcite, smectite, chlorite, mixed-layer illite-smectite, mixed-layer chlorite-smectite, illite, kaolinite, and pyrite. Pyrite occurs very rarely. These diagenetic phases are given in order of their paragenetic sequence as determined by petrographic analysis (Fig. 5).

The diagenetic minerals include (1) feldspar overgrowths; (2) quartz; (3) kaolinite; (4) smectite; (5) chlorite; (6) calcite; (7) mixed-layer illite-smectite; (8) mixed-layer chlorite-smectite; and (9) illite.

\section{Feldspar overgrowth}

The feldspar grains are composed of plagioclase and orthoclase in the thin sections of the Kömürlü and Penek Formation sandstones (Table 1). Feldspar overgrowths block the pores of the Kömürlü Formation sandstones (Fig. 6a, b) and negatively affect porosity and permeability. K-feldspar is common according to the EDS spectrum (Fig. 6a, b).

\section{Calcite}

Calcite was present in the pores as rhombohedral crystals (Fig. 6b). Early calcite cement was found in only one of the examined Kömürlü Formation sandstone samples at a depth of $2360 \mathrm{~m}$ (Table 1). Calcite cement was observed to primarily fill pores (Figs. 3a, 6b) and accounted for approximately $10 \%$ of the Kömürlü and Penek Formation sandstones. Calcite cement was observed to play a role in reducing the porosity and permeability of the Kömürlü Formation sandstones (Figs. 3a, 6b, 7a). In these sandstones, porosity is primarily related to the deposition time of the (Fig. 3a) calcite cement, while secondary porosity caused by dissolution of late calcite cement is present in both sandstones. The latter was particularly observed in deep zones of the Penek Formation sandstones at depths ranging from 3388 to 3570 m (Table 1; Fig. 4a, b). Macroporosity occurs when interconnected pores are mostly $2 \mu \mathrm{m}$ or more (up to $5 \mu \mathrm{m}$ ) in diameter (Hartmann 1989) and, in this area, resulted from leaching of the late calcite cement.

Calcite is usually dissolved in the thin sections and was found using SEM analysis (Figs. 3b, 4a, b, 7b). The dissolution porosity of calcite ranges between 7 and $10 \%$, with an 
Table 1 Petrographic data of the Kömürlü and Penek Formation sandstones for a single well, Aşkale sub-basin

\begin{tabular}{|c|c|c|c|c|c|c|c|c|c|}
\hline Depth (m) & $\begin{array}{l}\text { Forma- } \\
\text { tion }\end{array}$ & Framework grains & $\begin{array}{l}\text { Particle } \\
\text { size }\end{array}$ & $\begin{array}{l}\text { Rock clas- } \\
\text { sification }\end{array}$ & Sorting & Roundness & Authigenic phases & Cement & $\begin{array}{l}\text { Pore type and } \\
\text { thin-section } \\
\text { porosity }\end{array}$ \\
\hline $\begin{array}{l}2360 \\
\text { Sample } 1\end{array}$ & $\begin{array}{l}\text { Kömürlü } \\
\text { Fm. }\end{array}$ & $\begin{array}{l}\text { Matrix (14\%), ortho- } \\
\text { clase and plagio- } \\
\text { clase (10\%), quartz } \\
(8 \%) \text {, sedimentary, } \\
\text { and magmatic rock } \\
(68 \%)\end{array}$ & $\begin{array}{l}\text { Fine- } \\
\text { medium }\end{array}$ & $\begin{array}{l}\text { Lithic } \\
\text { arenite }\end{array}$ & Poorly & $\begin{array}{l}\text { Sub-angu- } \\
\text { lar-sub- } \\
\text { rounded }\end{array}$ & $\begin{array}{l}\text { Recrystallization, } \\
\text { calcite and clay } \\
\text { formation }\end{array}$ & $\begin{array}{l}\text { Early } \\
\text { calcite }\end{array}$ & $\begin{array}{l}\text { Intergrain } \\
\text { primary 5\% }\end{array}$ \\
\hline $\begin{array}{l}2370 \\
\text { Sample } 5\end{array}$ & $\begin{array}{l}\text { Kömürlü } \\
\text { Fm. }\end{array}$ & $\begin{array}{l}\text { Matrix }(6 \%), \text { quartz } \\
(6 \%), \text { chert }(4 \%), \\
\text { pyrite }(2 \%), \\
\text { orthoclase and } \\
\text { plagioclase (25\%), } \\
\text { and magmatic rock } \\
(57 \%)\end{array}$ & $\begin{array}{l}\text { Fine- } \\
\text { medium }\end{array}$ & $\begin{array}{l}\text { Lithic } \\
\text { arenite }\end{array}$ & Poorly & $\begin{array}{l}\text { Sub-angu- } \\
\text { lar-sub- } \\
\text { rounded }\end{array}$ & $\begin{array}{l}\text { Clay and organic } \\
\text { matter plaster }\end{array}$ & $\begin{array}{l}\text { Late } \\
\text { calcite }\end{array}$ & $\begin{array}{l}\text { Intragrain } \\
\text { (cracking } \\
\text { and dissolu- } \\
\text { tion) } 7 \% \text {, } \\
\text { secondary }\end{array}$ \\
\hline $\begin{array}{l}2388 \\
\text { Sample } 6\end{array}$ & $\begin{array}{l}\text { Kömürlü } \\
\text { Fm. }\end{array}$ & $\begin{array}{l}\text { Matrix (13\%), quartz } \\
(5 \%), \text { orthoclase } \\
(10 \%) \text {, sedimentary } \\
\text { and magmatic rock } \\
(70 \%)\end{array}$ & $\begin{array}{l}\text { Fine- } \\
\text { medium }\end{array}$ & $\begin{array}{l}\text { Lithic } \\
\text { arenite }\end{array}$ & Poorly & $\begin{array}{l}\text { Sub- } \\
\text { angular- } \\
\text { rounded }\end{array}$ & $\begin{array}{l}\text { Quartz overgrowth, } \\
\text { feldspar alteration, } \\
\text { and dissolution of } \\
\text { carbonate cement }\end{array}$ & $\begin{array}{l}\text { Late } \\
\text { calcite }\end{array}$ & $\begin{array}{l}\text { Dissolution } \\
\text { of carbonate } \\
\text { cement, } 8 \% \text {, } \\
\text { secondary }\end{array}$ \\
\hline $\begin{array}{l}3388 \\
\text { Sample } 9\end{array}$ & $\begin{array}{l}\text { Penek } \\
\text { Fm. }\end{array}$ & $\begin{array}{l}\text { Matrix }(10 \%), \text { quartz } \\
(5 \%), \text { orthoclase and } \\
\text { plagioclase }(10 \%), \\
\text { volcanic rock }(74 \%)\end{array}$ & $\begin{array}{l}\text { Medium- } \\
\text { coarse }\end{array}$ & $\begin{array}{l}\text { Lithic } \\
\text { arenite }\end{array}$ & $\begin{array}{l}\text { Moder- } \\
\text { ately }\end{array}$ & $\begin{array}{l}\text { Sub- } \\
\text { rounded }\end{array}$ & $\begin{array}{l}\text { Quartz overgrowth, } \\
\text { and dissolution of } \\
\text { carbonate cement }\end{array}$ & $\begin{array}{l}\text { Late } \\
\text { calcite }\end{array}$ & $\begin{array}{l}\text { Dissolution } \\
\text { of carbonate } \\
\text { cement } 10 \% \text {, } \\
\text { secondary }\end{array}$ \\
\hline $\begin{array}{l}3532 \\
\text { Sample } 10\end{array}$ & $\begin{array}{l}\text { Penek } \\
\text { Fm. }\end{array}$ & $\begin{array}{l}\text { Matrix }(8 \%) \text {, quartz } \\
(10 \%) \text {, orthoclase } \\
\text { and plagioclase } \\
(13 \%) \text {, sedimentary } \\
\text { and volcanic rock } \\
(69 \%)\end{array}$ & $\begin{array}{l}\text { Medium- } \\
\text { coarse }\end{array}$ & $\begin{array}{l}\text { Lithic } \\
\text { arenite }\end{array}$ & $\begin{array}{l}\text { Moder- } \\
\text { ately }\end{array}$ & $\begin{array}{l}\text { Sub- } \\
\text { rounded }\end{array}$ & Pore-filling chlorite & $\begin{array}{l}\text { Late } \\
\text { calcite }\end{array}$ & $\begin{array}{l}\text { Dissolution } \\
\text { of carbonate } \\
\text { cement } 9 \%, \\
\text { secondary }\end{array}$ \\
\hline $\begin{array}{l}3570 \\
\text { Sample } 11\end{array}$ & $\begin{array}{l}\text { Penek } \\
\text { Fm. }\end{array}$ & $\begin{array}{l}\text { Matrix }(8 \%) \text {, chert } \\
(2 \%), \text { quartz }(7 \%), \\
\text { orthoclase and } \\
\text { plagioclase }(13 \%), \\
\text { volcanic rock }(78 \%)\end{array}$ & Medium & $\begin{array}{l}\text { Lithic } \\
\text { arenite }\end{array}$ & $\begin{array}{l}\text { Moder- } \\
\text { ately }\end{array}$ & $\begin{array}{l}\text { Sub- } \\
\text { rounded }\end{array}$ & $\begin{array}{l}\text { Quartz overgrowth, } \\
\text { and dissolution of } \\
\text { carbonate cement }\end{array}$ & $\begin{array}{l}\text { Late } \\
\text { calcite }\end{array}$ & $\begin{array}{l}\text { Dissolution } \\
\text { of carbonate } \\
\text { cement } 10 \% \text {, } \\
\text { secondary }\end{array}$ \\
\hline
\end{tabular}

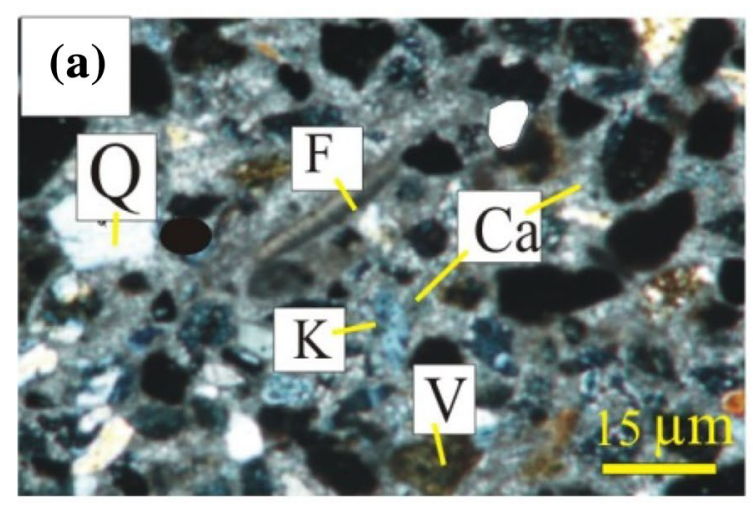

Fig. 3 Micrographs of the Kömürlü Formation sandstones. a Carbonate cement (Ca) is seen. $Q$ quartz, $K$ quartzite, $F$ fossil, $V$ volcanic rock, depth: $2365 \mathrm{~m}$, sample 3 . b Secondary porosity $(\mathrm{SP})$ is observed via dissolution of the carbonate cement $(\mathrm{Ca})$. Lithic arenite [closely

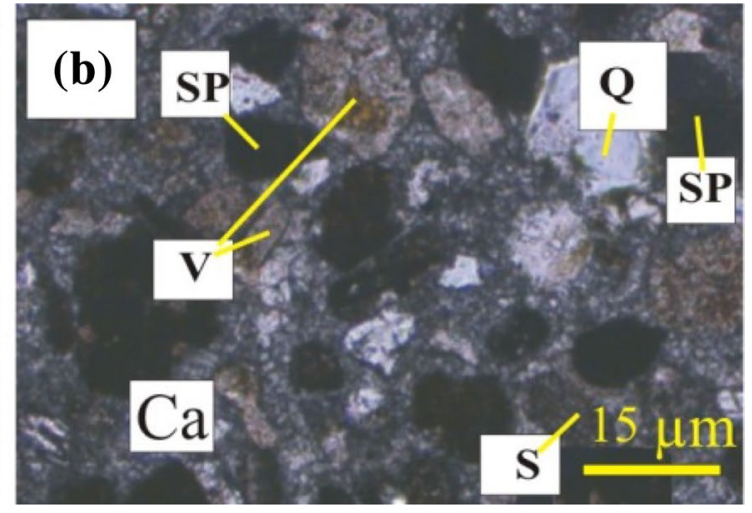

packed framework grains of sedimentary (S) and volcanic (V) rock fragment] and $Q$ quartz are observed in the photo, depth: $2368 \mathrm{~m}$, sample 4 
Fig. 4 Micrographs of the Penek Formation sandstones. a Idiomorphic quartz mineral Macroporosity is the result of leaching of the late calcite cement (Ca). $Q$ quartz, $S P$ secondary porosity, $S$ sedimentary rock, depth: $3388 \mathrm{~m}$, sample 9. b Again, dissolution of the carbonate cement $(\mathrm{Ca})$ is seen. $Q$ quartz, $S P$ secondary porosity is observed. Depth: $3532 \mathrm{~m}$, sample 10. c Medium, sub-rounded grains belong to Penek Formation appeared in the photo. $Q$ quartz, $F$ Feldspar, depth: $3570 \mathrm{~m}$, sample 11 (Q) is present in the photo.
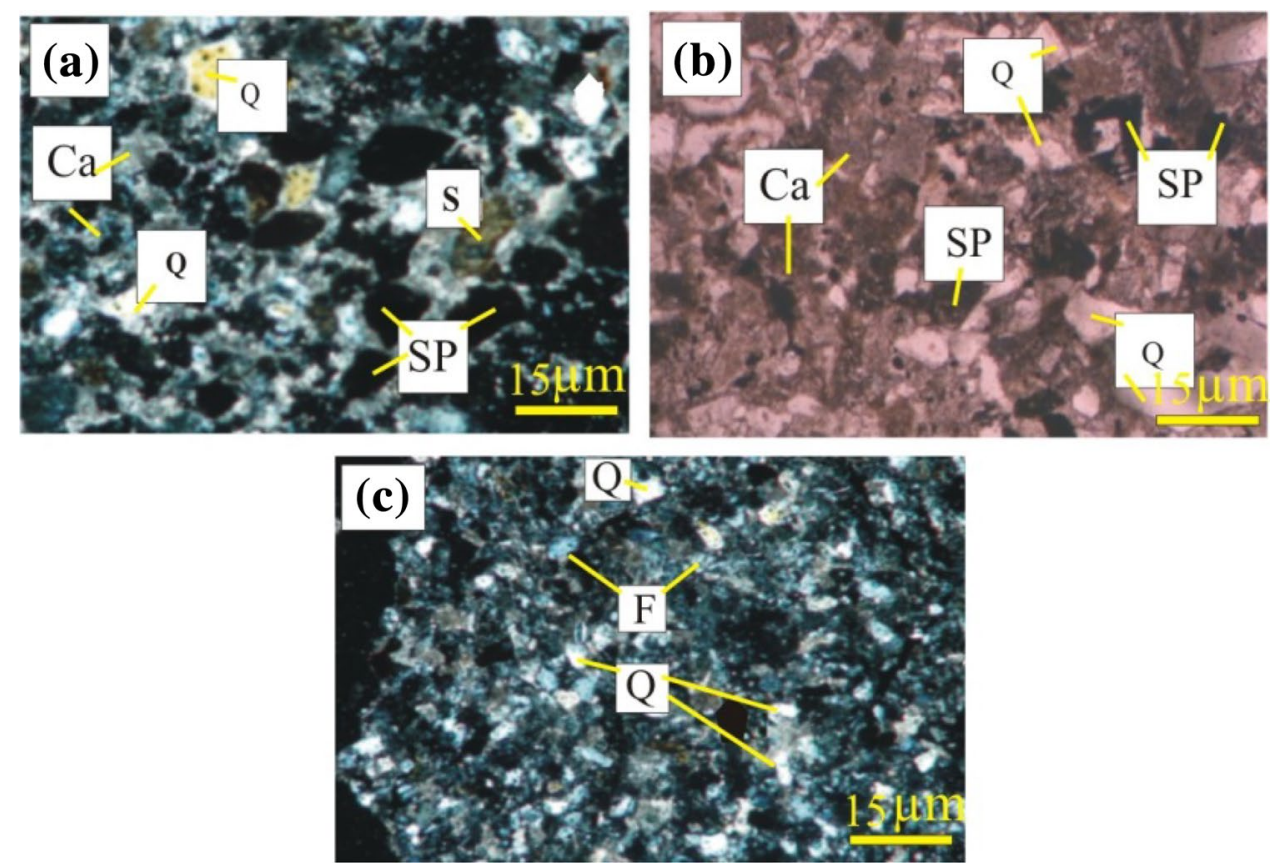

Fig. 5 Diagenetic sequence of the Kömürlü and Penek Formations of the Aşkale sub-basin

\section{Diagenetic Summary}

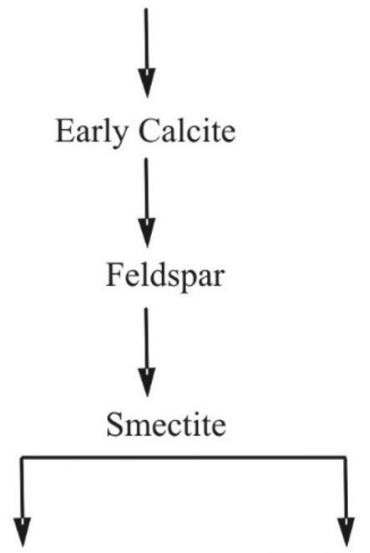

Mixed layer smectite-illite

(Potassium rich pore liquid)
Early Diagenesis

Mixed layer smectite-chlorite (Magnesium rich pore liquid)

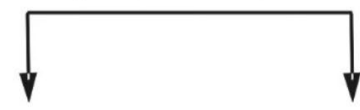

Illite Chlorite

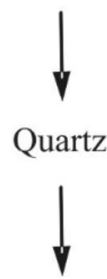

Dissolution of late calcite cementation and formation of secondary porosity 

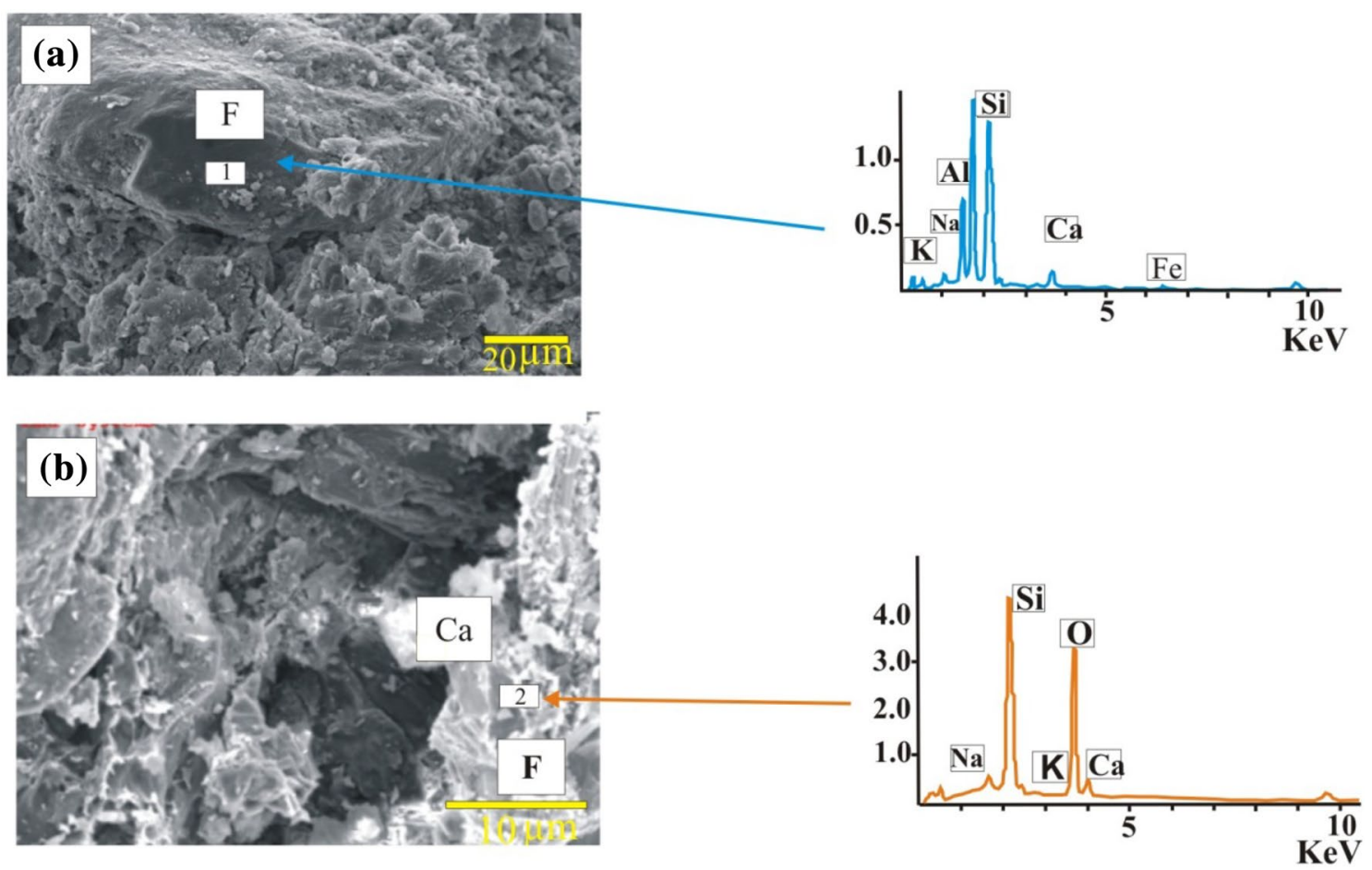

Fig. 6 Representative SEM micrographs and EDS traces for fine to medium sandstones of Kömürlü Formation. a Feldspar overgrowth (F) blocked the pore. b Feldspar overgrowth $(\mathrm{F})$ and calcite $(\mathrm{Ca})$ min-

average of $8 \%$, and is most abundant in the Penek Formation at depths between 3388 and $3570 \mathrm{~m}$ (Table 1).

\section{Smectite}

XRD studies indicated that smectites are present in the Kömürlü and Penek Formation sandstones at depths ranging from 2362 to $3570 \mathrm{~m}$ (Supplementary Information; minerals were abbreviated from Whitney and Evans 2010). Diagenetic smectite shows a minor flaky morphology in SEM images of the Kömürlü Formation sandstones (Fig. 8a) and occurs mostly as grain coatings and pore fillings in the Penek Formation sandstones (Fig. 8b). The diagenetic smectite showed EDS peaks for $\mathrm{Na}, \mathrm{Mg}$, and Fe (Fig. 8a, b). Smectite minerals in these sandstones commonly destroyed much of the original intergranular porosity. The pore throats typically range in size from 2 to $5 \mu \mathrm{m}$.

4. Mixed-layer 1llite-smectite

XRD studies indicated that mixed-layer illite-smectite is present in the Kömürlü Formation sandstones at depths between 2362 and $2380 \mathrm{~m}$ (Supplementary Information). eral are present as a pore filling in the SEM micrographs. K-feldspar is common in the EDS spectrum (a single well, depth: $2362 \mathrm{~m}$, sample 2)

The petrographic relationship suggests that diagenetic illite followed the formation of illite-smectite (Fig. 5). In this study, the illite exhibited a neoformation origin, which requires K-rich alkaline pore fluids. EDS of the diagenetic illite showed high levels of K present in the Kömürlü Formation sandstones (Fig. 9a).

Diagenetic illite mostly occurred as grain coatings with a flaky morphology in the SEM micrographs of the Kömürlü Formation sandstones (Fig. 9a).

\section{Quartz}

Quartz was seen with thin-section petrography. The quartz cements are a minor phase after the authigenic mixed-layer illite-smectite (Fig. 5). There may be two important sources of Si that make up quartz in the Kömürlü and Penek Formation sandstones. These sources are as follows:

I. Pressure solutions and

II. Smectite-illite transformations (Boles and Franks 1979).

An increase in the shale/sandstone ratio and an increase in smectite-illite conversion rates were observed at the bottom of the Kömürlü Formation (Büyükutku and Şahintürk 2006).

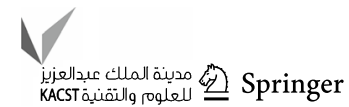




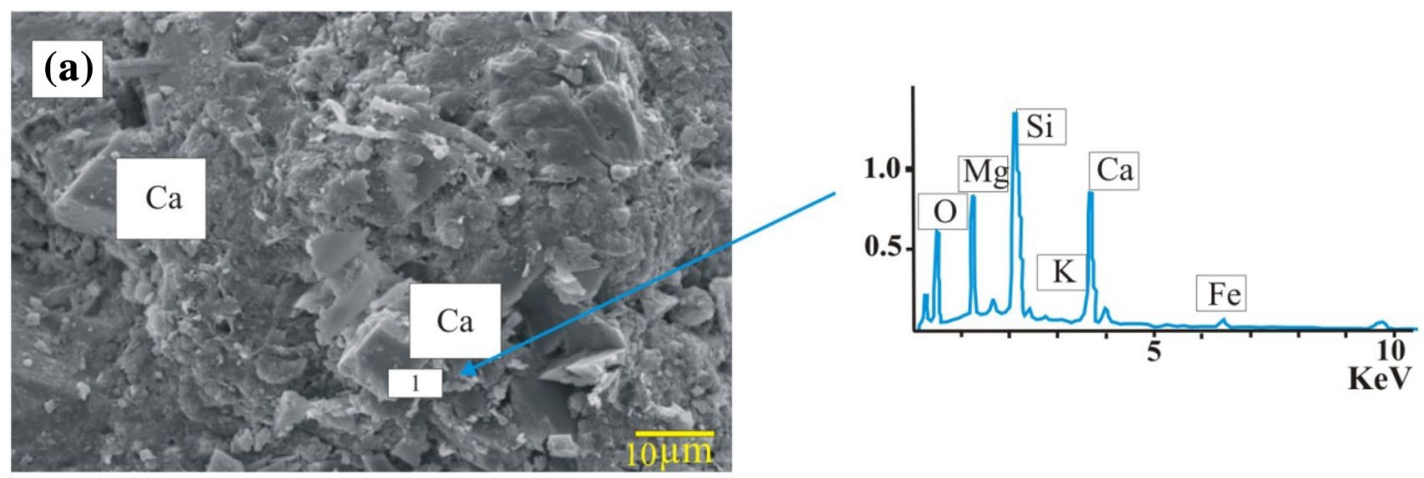

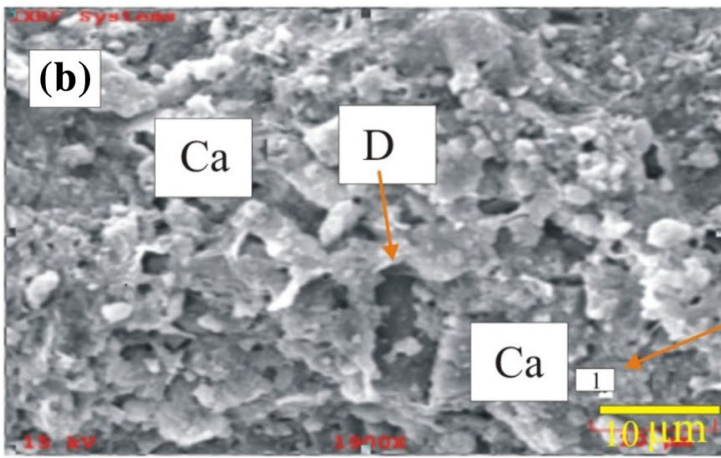

Fig. 7 Representative SEM micrographs and EDS traces for fine to medium sandstones of the Kömürlü Formation. a Early calcite mineral $(\mathrm{Ca})$ is present as a pore filling in the SEM micrographs. Dominant calcite $(\mathrm{Ca})$ peak is seen in the EDS spectrum (a single well,

6. Kaolinite

Kaolinite was seen in the XRD analysis but not in the SEM results. Strong reflections of kaolinite appeared at $2.52 \mathrm{~A}^{\mathrm{o}}$ (Supplementary Information). The formation of kaolinite requires acidic solutions and the maturation of organic matter in shale.

\section{Chlorite}

The chlorite minerals show a flaky morphology and occur as grain coatings in the medium- to coarse-grained Penek Formation sandstones. Grain coatings of chlorite were seen on the quartz minerals in some samples. EDS analyses showed that the diagenetic chlorite is $\mathrm{Mg}$ rich in the Penek Formation sandstones (Figs. 5, 9b). The grain-coating chlorite had a thickness range of $1-2 \mu \mathrm{m}$ in the SEM analysis.

8. Mixed-layer chlorite-smectite

XRD studies indicated that mixed-layer chloritesmectite is present in the study well at depths from 3388 to $3570 \mathrm{~m}$ (Supplementary Information). The for- depth: $2368 \mathrm{~m}$, sample 4). b Dissolution (D) of the late diagenetic calcium cement $(\mathrm{Ca})$ produces the secondary porosity. Dominant calcium cement $(\mathrm{Ca})$ peak is $\mathrm{Ca}$ in the EDS spectrum (a single well, Penek Formation, depth: 3100 m, sample 8)

mation of mixed-layer chlorite-smectite requires $\mathrm{Mg}$ rich alkaline pore fluids (Fig. 5); however, mixed-layer chlorite-smectite was not observed in the SEM results. The clay fractions in the Penek Formation sandstone were composed mainly of mixed-layer chlorite-smectite, which was identified by (001) basal reflections at $14.82 \mathrm{~A}^{\mathrm{o}}$ in the XRD patterns of oriented clay fractions (Supplementary Information). The characteristic peak of mixed-layer chlorite-smectite for the air-dried fraction with a size $<2 \mu$ m expanded to approximately $14.91 \mathrm{~A}^{\mathrm{o}}$ in the ethylene glycol-saturated samples and contracted to $14.67 \mathrm{~A}^{\circ}$ when heated to $550{ }^{\circ} \mathrm{C}$ (Supplementary Information).

\section{FTIR-ATR analysis}

We analyzed shale samples by FTIR spectroscopy using the ATR technique (Figs. 10,11). The FTIR evaluation was conducted according to Van der Marel and Beutelspacher (1976). The FTIR spectra of both samples showed peaks near $3600-3700 / \mathrm{cm}$, consistent with the $\mathrm{OH}$ stretching vibrations of structural hydroxyls. 

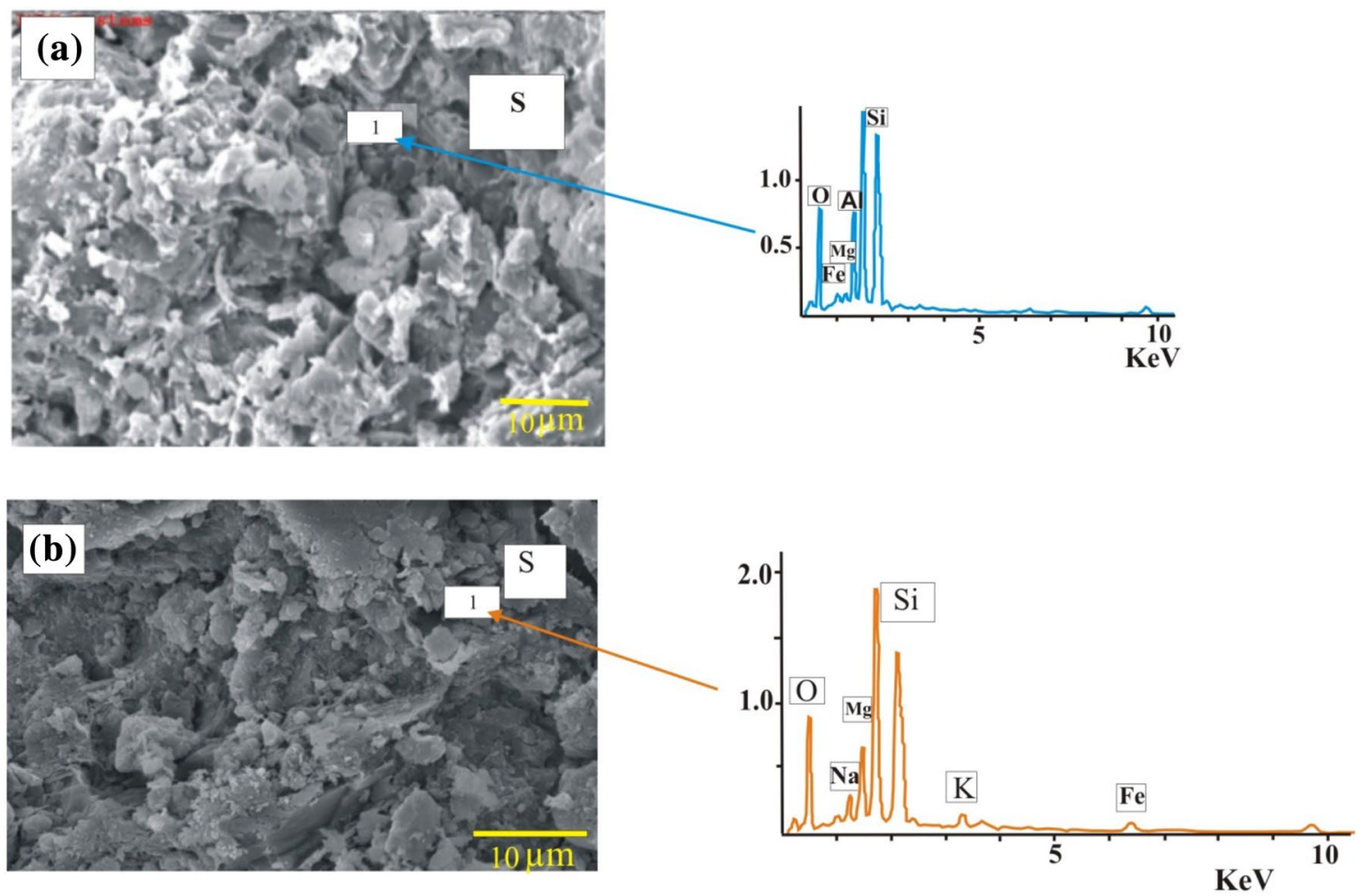

Fig. 8 Representative SEM micrographs and EDS traces for the Kömürlü and Penek Formation sandstones. a Smectite (S) mineral is shown as a flake morphology. Dominant smectite (S) peaks are $\mathrm{Mg}$, $\mathrm{Fe}, \mathrm{Al}, \mathrm{Si}$, and $\mathrm{O}$ elements in the EDS spectrum (a single well, The

As shown in Fig. 10, hydroxyl peaks occurred at 3705, 3667,3624 , and $3603 / \mathrm{cm}$. The characteristic hydroxyl peaks at $3624 / \mathrm{cm}, 3667 / \mathrm{cm}$, and $3705 / \mathrm{cm}$ show the presence of kaolinite, similar to a previous work (Hassouta et al. 1999). The $\mathrm{CO}_{3}$ peak at $1430 / \mathrm{cm}$ points to the presence of dolomite. The $\mathrm{CO}_{3}$ peak at $710 / \mathrm{cm}$ shows the presence of calcite, in accordance with the SEM and EDS results. The peak at $1024 / \mathrm{cm}$ corresponds to $\mathrm{C}-\mathrm{O}$ and $\mathrm{C}-\mathrm{N}$ bonds. An $\mathrm{Si}-\mathrm{O}$ bond at 1019/cm was observed, similar to previous studies (Hassouta et al. 1999; Madejova and Komadel 2001). The peak at $916 / \mathrm{cm}$ corresponds to $\mathrm{Al}_{2} \mathrm{OH}$, as previously seen (Hassouta et al. 1999). In addition, $\mathrm{CH}_{3}(1447,1373,1220$, and $1217 / \mathrm{cm}$ ) peaks are evident in Fig. 10. The $\mathrm{CH}_{3}$ peaks show the presence of saturated hydrocarbons, which supports the results of an earlier work (Büyükutku and Şahintürk 2005).

In Fig. 11, hydroxyl peaks occurred at 3700, 3668, 3626, and $3604 / \mathrm{cm}$. The characteristic hydroxyl peak at $3668 / \mathrm{cm}$ shows the presence of kaolinite, which is in accordance with the XRD results (Supplementary Information). An Si-O bond at $1018 / \mathrm{cm}$ was observed. The peak at $916 / \mathrm{cm}$ corresponds to $\mathrm{Al}_{2} \mathrm{OH}$, similar to that shown in Fig. $10 . \mathrm{CH}_{3}$ $(1445,1373,1240,1217$, and $1190 / \mathrm{cm})$ and $\mathrm{CH}_{2}(1470 / \mathrm{cm})$
Kömürlü Formation, depth: 2368 m, sample 4). b Smectite (S) mineral is present as a grain coat. Dominant smectite (S) peaks are $\mathrm{Na}$, $\mathrm{Mg}$, and Fe elements in the EDS spectrum (a single well, the Penek Formation, depth: $3050 \mathrm{~m}$, sample 7)

peaks are also visible in Fig. 11 and show the presence of saturated hydrocarbons, similar to that shown in Fig. 10.

\section{Log interpretation}

Sandstone porosity was obtained from the sonic, density, and neutron logs of the studied well. Sonic logs ignore secondary porosity (dissolution and fractures) and respond primarily to intergranular porosity; density and neutron logs respond to the total porosity. The density-neutron crossplots yield the total porosity (Schlumberger 1986) and were used for the Kömürlü and Penek sandstone samples in this study.

The $\log$ values for a typical sandstone reservoir are as follows:

GR: 30-50 API, spontaneous potential (SP): very negative, variable values $\mathrm{mV}$, DT: $55 \mu \mathrm{s} / \mathrm{ft}$, resistivity (LLD) $>$ $10 \Omega \mathrm{m}$, NPHI: $0.30-0.35 \mathrm{~m}^{3} / \mathrm{m}^{3}$, and RHOB: $2.4-2.88 \mathrm{~g} /$ $\mathrm{cm}^{3}$ (Schlumberger 1984).

Log measurement was performed in a single well for the Kömürlü and Penek Formation sandstones in the Aşkale sub-basin (Fig. 12). 

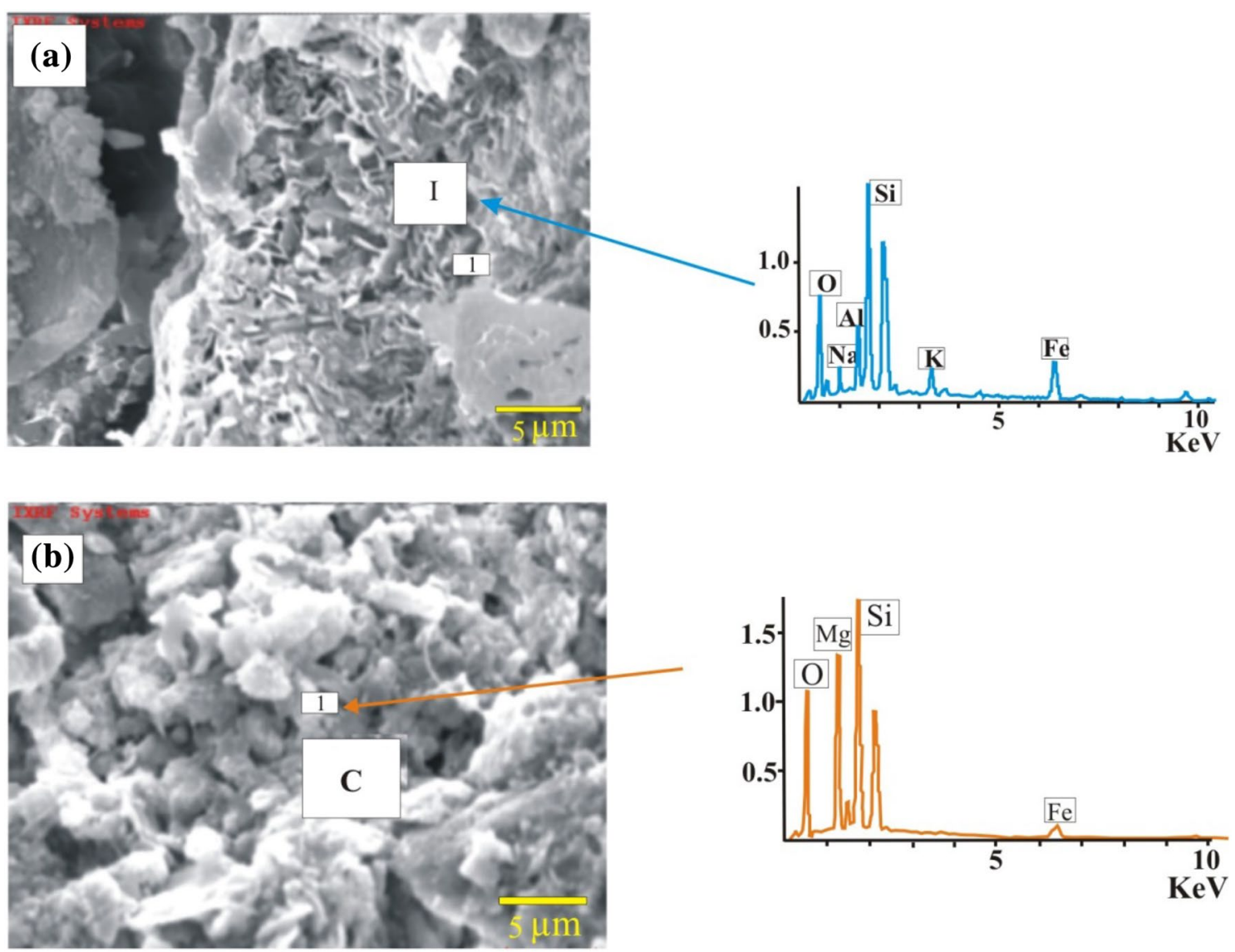

Fig. 9 Representative SEM micrographs and EDS traces for the Kömürlü and Penek Formations sandstones. a Illite (I) minerals are present as a grain coating and flake morphology in the SEM micrographs. Dominant illite (I) peak is $\mathrm{K}$ element in the EDS spectrum (a single well, The Kömürlü Formation, depth: 2368 m, sample 4). b Chlorite (C) minerals are seen as a flake morphology in the SEM micrographs. Dominant chlorite $(\mathrm{C})$ peaks are $\mathrm{Mg}$ elements in the EDS spectrum (a single well, the Penek Formation, depth: $3050 \mathrm{~m}$, sample 7)
Fig. 10 The FTIR spectrum of sandstone-shale (the Kömürlü Formation) well sample. A single well; depth: $2360 \mathrm{~m}$, sample 1

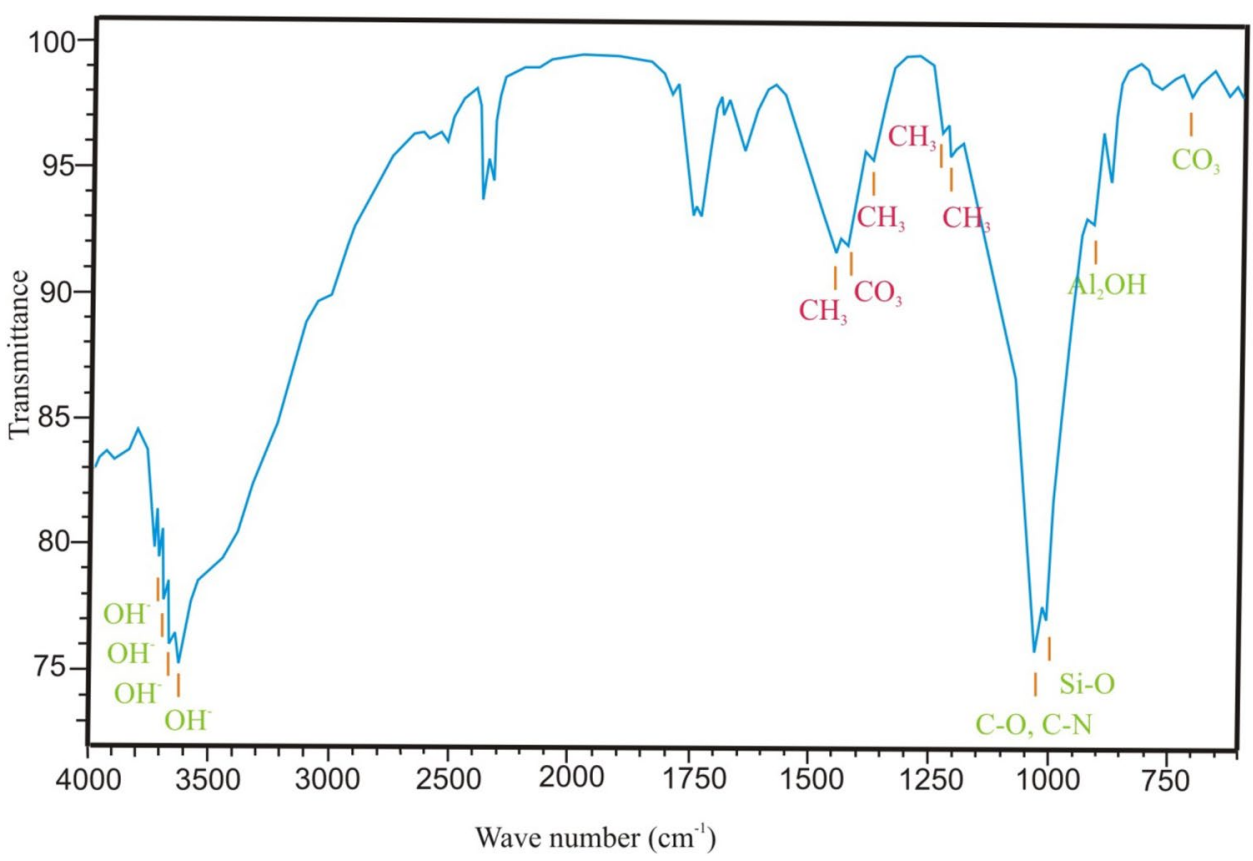


Fig. 11 The FTIR spectrum of sandstone-shale (the Penek Formation) well sample. A single well; depth: $3532 \mathrm{~m}$, sample 10

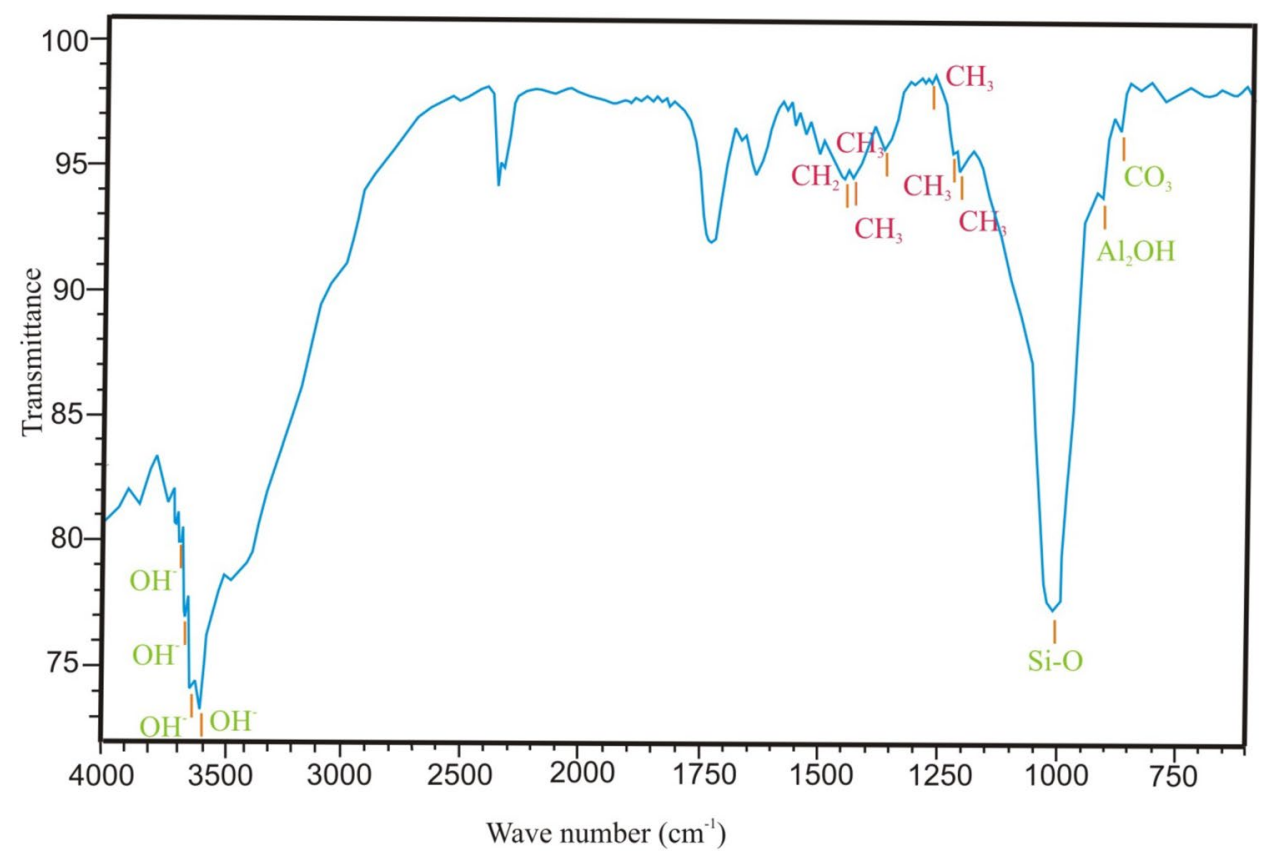

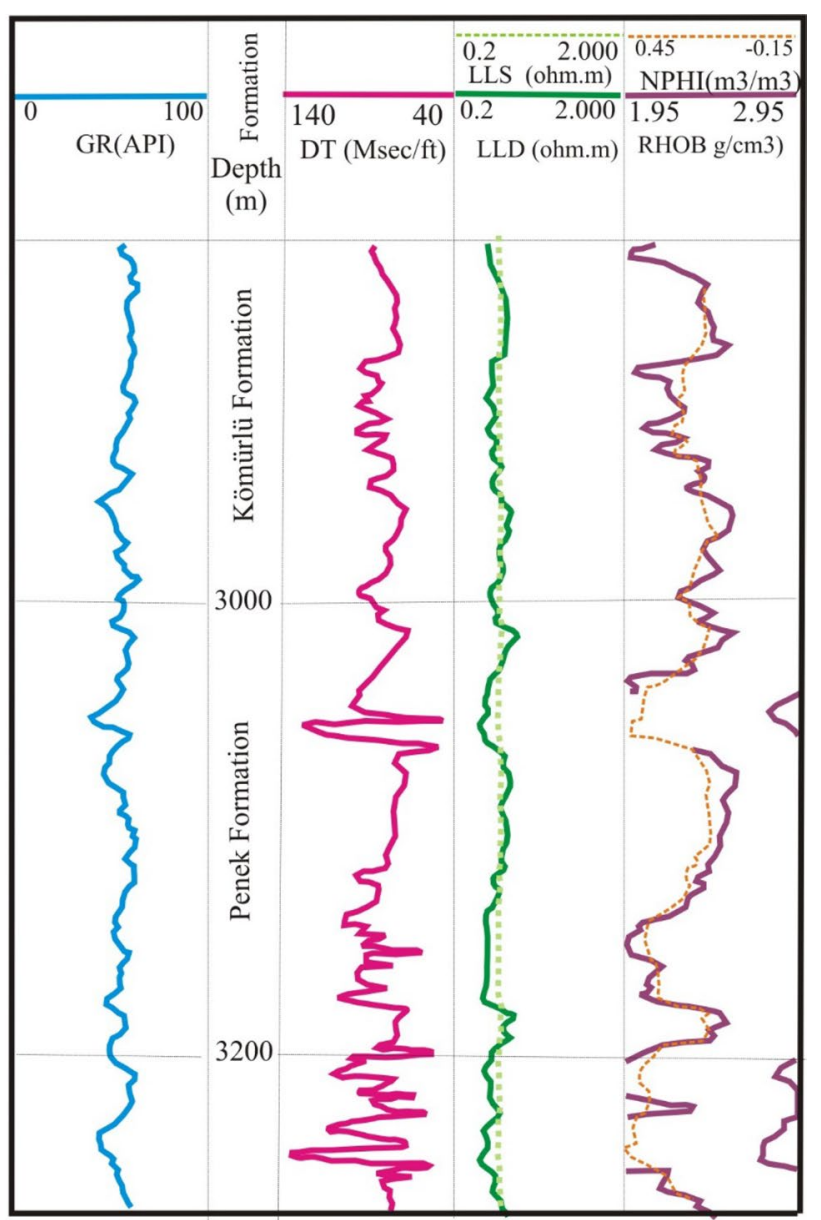

Fig. 12 Well logs of the Kömürlü and Penek Formations
Generally, the mean values of the Kömürlü Formation sandstones are GR $=75$ API, DT $=55-70 \mu \mathrm{s} / \mathrm{ft}$, resistivity $(\mathrm{LLD})=250 \Omega \mathrm{m}, \mathrm{NPHI}=0.30 \mathrm{~m}^{3} / \mathrm{m}^{3}$, and $\mathrm{RHOB}=2.30 \mathrm{~g} /$ $\mathrm{cm}^{3}$.

The mean values of the Penek Formation sandstone are $\mathrm{GR}=48 \mathrm{API}, \mathrm{DT}=60 \mu \mathrm{s} / \mathrm{ft}, \mathrm{LLD}=350 \Omega \mathrm{m}$, $\mathrm{NPHI}=0.35 \mathrm{~m}^{3} / \mathrm{m}^{3}$, and RHOB $=2.38 \mathrm{~g} / \mathrm{cm}^{3}$.

Comparing the density log with the neutron log, we can see that the neutron log curve has lower values (down to a depth of $2362 \mathrm{~m}$ ) in the Kömürlü Formation sandstones and higher values elsewhere, especially at the depths of 3100-3200 $\mathrm{m}$ in the Penek Formation sandstones (Fig. 12; Table 2).

There is a separation in the density-neutron log that indicates an increase in the permeability of a sandstone reservoir (Özkanlı 1990). These logs show small density-neutron crossovers, with a separation at the Penek Formation (from 3050 to $3150 \mathrm{~m}$ depth). A large density-neutron crossover is an indication of hydrocarbons (i.e., gas) (Schlumberger 1986). Therefore, the Kömürlü and Penek Formation sandstones have poor reservoir rock properties on the basis of the density-neutron log responses.

The average total porosity values of the Penek and Kömürlü Formation sandstones from the well logs (neutron and density $\operatorname{logs}$ ) are $18-25 \%$ and $15-20 \%$, respectively (Fig. 13).

The shale volume $V_{\text {sh }}$ in the Kömürlü and Penek Formation sandstones was estimated using the following equation (Schlumberger 1996):

$V_{\mathrm{sh}}=\mathrm{GR}_{\mathrm{log}}-\mathrm{GR}_{\min } /\left(\mathrm{GR}_{\max }-\mathrm{GR}_{\min }\right)$, 
Table 2 Sonic, neutron log, and density log porosity values of the Kömürlü and Penek Formation sandstones, Aşkale sub-basin

\begin{tabular}{|c|c|c|c|c|c|c|c|}
\hline \multicolumn{4}{|c|}{ Kömürlü Formation (2348-2380 m) } & \multicolumn{4}{|c|}{ Penek Formation (3060-3100 m) } \\
\hline Depth (m) & Sonic porosity & Neutron log & Density log & Depth (m) & Sonic porosity & Neutron log & Density $\log$ \\
\hline 2348 & 2 & 0.15 & 2.55 & 3060 & 12 & 0.41 & 2.15 \\
\hline 2350 & 0.5 & 0.50 & 2.65 & 3062 & 13 & 0.30 & 2.05 \\
\hline 2352 & 0.5 & 0.50 & 2.56 & 3064 & 0.2 & 0.35 & 2.33 \\
\hline 2354 & 2 & 0.90 & 2.60 & 3066 & 2 & 0.36 & 2.25 \\
\hline 2356 & 4 & 0.21 & 2.55 & 3068 & 5 & 0.27 & 2.37 \\
\hline 2358 & 4 & 0.15 & 2.52 & 3070 & 5 & 0.29 & 2.45 \\
\hline 2360 & 15 & 0.39 & 2.64 & 3072 & 4 & 0.18 & 2.50 \\
\hline 2362 & 10 & 0.38 & 2.02 & 3074 & 11 & 0.29 & 2.25 \\
\hline 2364 & 7 & 0.27 & 2.35 & 3076 & 11 & 0.90 & 2.70 \\
\hline 2366 & 13 & 0.23 & 2.05 & 3078 & 5 & 0.17 & 2.42 \\
\hline 2368 & 7 & 0.27 & 1.95 & 3080 & 8 & 0.21 & 2.25 \\
\hline 2370 & 11 & 0.32 & 2.03 & 3082 & 8 & 0.24 & 2.32 \\
\hline 2372 & 5 & 0.25 & 2.45 & 3084 & 4 & 0.23 & 2.45 \\
\hline 2374 & 5 & 0.16 & 2.47 & 3086 & 2 & 0.18 & 2.40 \\
\hline 2376 & 5 & 0.14 & 2.52 & 3088 & 7 & 0.21 & 2.45 \\
\hline 2378 & 11 & 0.21 & 2.40 & 3090 & 5 & 0.26 & 2.30 \\
\hline \multirow[t]{5}{*}{2380} & 12 & 0.20 & 2.45 & 3092 & 6 & 0.45 & 2.75 \\
\hline & & & & 3094 & 6 & 0.41 & 2.85 \\
\hline & & & & 3096 & 8 & 0.40 & 2.8 \\
\hline & & & & 3098 & 8 & 0.35 & 1.95 \\
\hline & & & & 3100 & 7 & 0.33 & 1.95 \\
\hline
\end{tabular}

where $\mathrm{GR}_{\log }=$ gamma ray log value for shaly sand; $\mathrm{GR}_{\min }$ = gamma ray minimum value for clean sand; and $\mathrm{GR}_{\max }=$ gamma ray maximum value for the shale zone.

The most impermeable zones indicate shale intervals with a high concentration of clay minerals, which decreases the effective porosity and permeability. Thus, in both the Kömürlü and Penek Formation sandstones, the clay

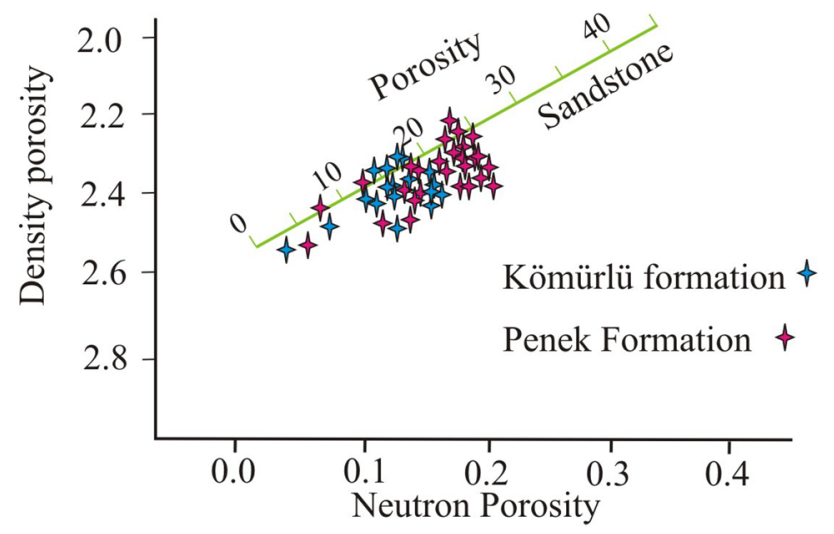

Fig. 13 Density-neutron porosity cross-plot. This graphic gives total porosity values. A single well; depth: the Kömürlü formation: 23482380 m, the Penek Formation: 3060-3100 m percentage (Table 3 ) could be determined in detail by the gamma ray log between 2348 and $3100 \mathrm{~m}$ depth. The average clay percentages of the Penek and Kömürlü Formation sandstones were $59.4 \%$ and $58.4 \%$, respectively, showing that these sandstones have a high clay volume. Therefore, the Kömürlü and Penek Formation sandstones have poor reservoir rock properties on the basis of the gamma ray log responses.

Petrophysical log interpretations used for the characterization of reservoir sandstones are very useful for the evaluation of reservoir rocks in terms of their porosity, water saturation and permeability to distinguish between gas-, oil- and water-bearing strata by observing effective porosity and relative permeability values (Schlumberger 1996).

The lithology in the studied well was interpreted using a computer programme (Elan), which can distinguish between clean sand, shale, carbonate beds, and other lithologies (Fig. 14). Water saturation (Sw) and effective porosity $\left(\Phi_{\mathrm{ef}}\right)$ of the Kömürlü and Penek Formations were calculated from Elan programme.

At irreducible water saturation, Timur's equation (1968) is applied to determine the permeability $(K)$ of the Kömürlü and Penek Formations as follows:

$\mathrm{K}(\mathrm{mD})=0.136 \cdot \phi_{\mathrm{ef}}{ }^{4.4} / \mathrm{Sw}^{2}$, 
Table 3 Clay percentages of the Kömürlü and Penek Formation sandstones, Aşkale sub-basin

\begin{tabular}{|c|c|c|c|}
\hline \multicolumn{2}{|c|}{$\begin{array}{l}\text { Kömürlü } \\
\text { Kömürlü Formation (2348-2380 m) }\end{array}$} & \multicolumn{2}{|c|}{$\begin{array}{l}\text { Penek } \\
\text { Penek Formation (3060- } \\
3100 \mathrm{~m})\end{array}$} \\
\hline Depth (m) & Clay \% & Depth (m) & Clay $\%$ \\
\hline 2348 & 76 & 3060 & 37.5 \\
\hline 2350 & 0 & 3062 & 50.0 \\
\hline 2352 & 4 & 3064 & 67.5 \\
\hline 2354 & 20 & 3066 & 67.5 \\
\hline 2356 & 40 & 3068 & 77.5 \\
\hline 2358 & 40 & 3070 & 62.5 \\
\hline 2360 & 36 & 3072 & 52.5 \\
\hline 2362 & 76 & 3074 & 60.0 \\
\hline 2364 & 92 & 3076 & 7.5 \\
\hline 2366 & 80 & 3078 & 42.5 \\
\hline 2368 & 84 & 3080 & 62.5 \\
\hline 2370 & 72 & 3082 & 50.0 \\
\hline 2372 & 56 & 3084 & 60.0 \\
\hline 2374 & 88 & 3086 & 67.5 \\
\hline 2376 & 44 & 3088 & 60.0 \\
\hline 2378 & 90 & 3090 & 70.0 \\
\hline \multirow[t]{5}{*}{2380} & 94 & 3092 & 35.0 \\
\hline & & 3094 & 82.5 \\
\hline & & 3096 & 82.5 \\
\hline & & 3098 & 75.0 \\
\hline & & 3100 & 77.5 \\
\hline Total clay $\%$ & 992 & Total clay $\%$ & 1247.5 \\
\hline Average clay \% & 58.4 & Average clay \% & 59.4 \\
\hline
\end{tabular}

Clay volume $\mathrm{GR} \%=\left[\left(\mathrm{GR}_{\log }-\mathrm{GR}_{\min }\right) /\left(\mathrm{GR}_{\max }-\mathrm{GR}_{\min }\right)\right] \times 100 \mathrm{GR}$ : gamma ray, the Kömürlü Formation: $\mathrm{GR}_{\min }=10 \mathrm{API} \mathrm{GR}_{\max }=60$ API, the Penek Formation: $\mathrm{GR}_{\min }=25$ API GR $\max _{\max }=65$ API

where $K$ is permeability, $\Phi_{\text {ef }}$ effective porosity and $S w$ is irreducible water.

The average shale-corrected porosities (effective) vary between 4 and $15 \%$ and generally increase with depth (after $2850 \mathrm{~m}$ ). Similarly, the average permeability values are less than $1 \mathrm{mD}$ (Figs. 15, 16 porosity permeability diagrams). The average water saturation of these units varies between 88.5 and $100 \%$. These values are generally high for the sandstones units in the well, indicating a very low hydrocarbon content.

\section{Reservoir quality}

To evaluate the producibility of a reservoir, determining how easily fluid can flow through the pore system is necessary. Additionally, lithology can play an important role in the production of a reservoir.
The studied sandstones are predominantly classified as litharenite. The Kömürlü sandstones were composed of fineto medium-grained, poorly sorted, and sub-angular to subrounded grains. The Penek sandstones consist of mediumto coarse-grained, moderately-poorly sorted, sub-rounded grains. Thus, according to the petrographic analysis, two sandstones show poor reservoir qualities.

Observations by thin-section petrography and SEM indicated that the porosity in both sandstones is mostly microporous and rarely macroporous.

Diagenesis in the Kömürlü and Penek Formation sandstones commonly destroyed much of the original intergranular porosity, dissolved grains, and produced clay-filled pores. The pore throats typically range in size from 1 to $5 \mu \mathrm{m}$ and represent only a small portion of the total porosity. Pore throat sizes (diameters) are generally greater than $2 \mu \mathrm{m}$ in conventional reservoir rocks (Nelson 2009).

The most important diagenetic phases of the Kömürlü and Penek Formation sandstones are quartz, feldspar overgrowth, calcite, smectite, chlorite, mixed-layer illite-smectite, mixed-layer chlorite-smectite, illite, kaolinite, and pyrite. Authigenic clays and feldspar overgrowths fill pore spaces and reduce porosity. Significant porosity was observed, especially with the dissolution of late calcite cement in the Penek Formation. The effect of diagenetic minerals on porosity is greater than that of secondary dissolution.

The average total porosity values of the Penek and Kömürlü Formation sandstones from the well logs (neutron and density logs) were $18-25 \%$ and $15-20 \%$, respectively (Fig. 13). Density-neutron logs showed high total porosity in the Penek Formation sandstones (Table 2; Fig. 13).

The clay percentage (Table 3) was evaluated in detail by the gamma ray log between 2348 and $3100 \mathrm{~m}$ depth in the Kömürlü and Penek Formation sandstones. The average clay percentages of the Penek and Kömürlü Formation sandstones were $59.4 \%$ and $58.4 \%$, respectively.

The Kömürlü and Penek Formation sandstones have undergone extensive diagenesis and have low porosity and permeability (Figs. 15, 16). Principal diagenetic processes controlled the final porosity and permeability. Diagenesis has destroyed much of the original intergranular porosity, dissolved late diagenetic calcite, and produced clay-filled pores.

Much of the present porosity is secondary porosity occurring within late diagenetic carbonate cement. Pores within late diagenetic cements typically range from 1 to $5 \mu \mathrm{m}$ in diameter but may be partly filled by authigenic clays, thereby reducing the porosity and permeability. The pore throats range in diameter from 1 to $5 \mu \mathrm{m}$. These pore throats represent a small portion of the total porosity, as observed by SEM, but exert a strong control on permeability. 


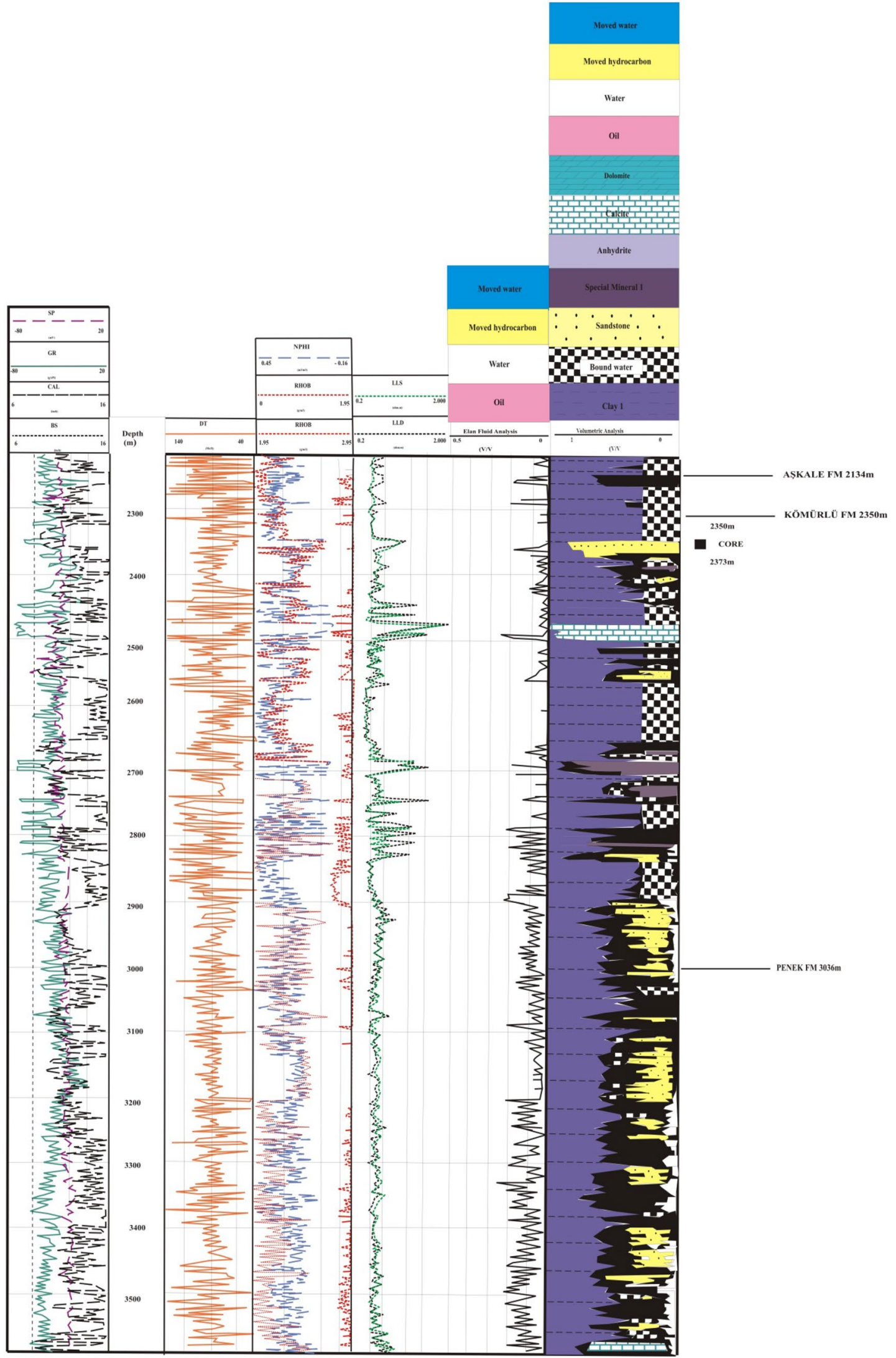

Fig. 14 Wire-line logs and lithology section from computer processes 


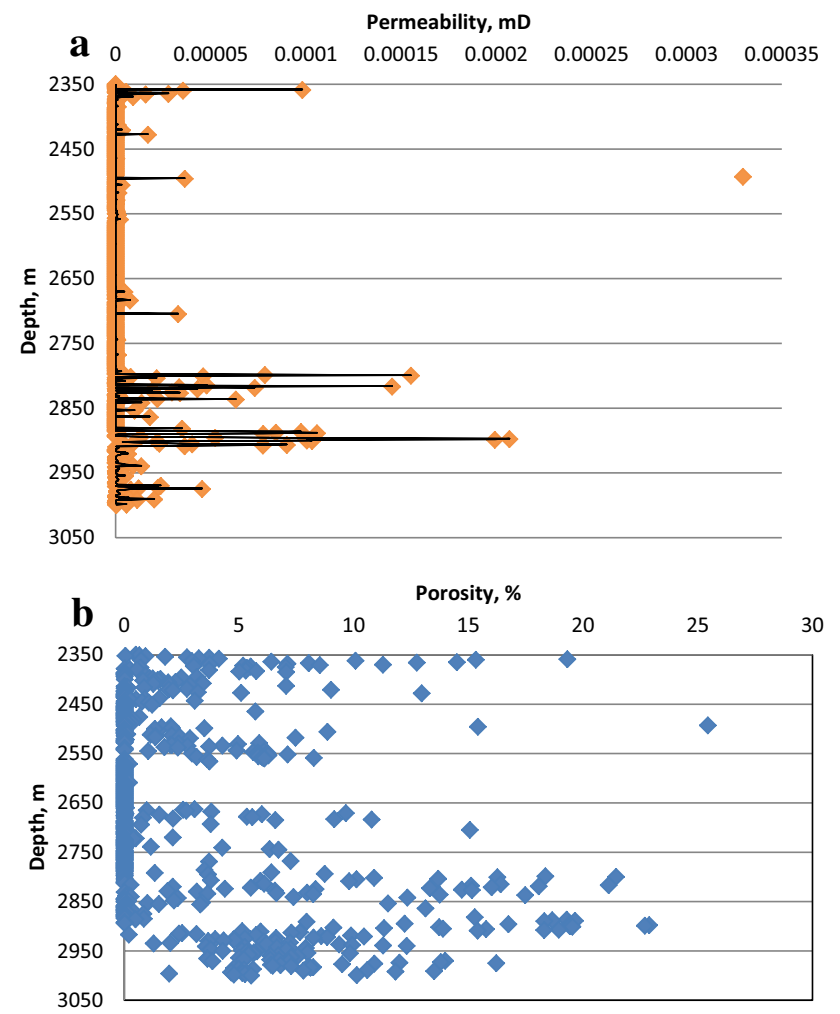

Fig. 15 a Depth-permeability cross-plot of Kömürlü Formation. b Depth-porosity cross-plot of Kömürlü Formation

Two sandstones with similar pore throat sizes and distributions but differing amounts of leached late diagenetic calcite cement could be expected to display similar permeability but would exhibit porosities that differ by the amount of leached late diagenetic calcite pore space. The two sandstones have small permeability-porosity trends according to well $\log$ interpretations (Figs. 15, 16).

In this study, porosity and permeability values could also be measured in cores of the Kömürlü sandstones (Table 4). According to Table 4 , the average porosity value is $11.3 \%$ and the average permeability is $1.2 \mathrm{mD}$, indicating poor reservoir properties.

Shales from the Kömürlü and Penek Formations show source rock features. Their total organic carbon content is approximately $1-3 \%$, and the vitrinite reflectance value is between 0.4 and 1\% (Büyükutku and Şahintürk 2005).

According to the FTIR results, the $\mathrm{CH}_{3}$ and $\mathrm{CH}_{2}$ peaks show the presence of saturated hydrocarbons in the fine- to medium-grained sandstones of the Kömürlü Formation and medium- to coarse-grained sandstones of the Penek Formation samples, supporting the source rock potential of the Aşkale sub-basin (Tekin 2002).

\section{Conclusions}

The Kömürlü and Penek Formation sandstones are classified as litharenites in the Aşkale sub-basin. Early and late carbonate cement and secondary porosity due to dissolution of late carbonate cement were observed in thin sections and SEM images. The most important diagenetic phases of the Kömürlü and Penek Formation sandstones are quartz, feldspar overgrowth, calcite, smectite, chlorite, mixed-layer illite-smectite, mixed-layer chlorite-smectite, illite, kaolinite, and pyrite. Pyrite occurred very rarely. These diagenetic phases are given in the order of their paragenetic sequence, as seen in the petrographic analyses. Diagenetic minerals negatively affected the porosity and permeability of the Kömürlü and Penek Formations. Significant porosity developments were observed, especially with the dissolution of calcite cement in deep zones of the Penek Formation. The dissolution of calcium cement produced secondary porosity, and the effect of diagenetic minerals on porosity is greater than that of secondary dissolution.

Kaolinite, dolomite, and calcite minerals were observed in the FTIR spectra. In the fine- to medium-grained sandstones of the Kömürlü Formation and the medium- to coarse-grained sandstones of the Penek Formation samples, the FTIR studies showed $\mathrm{CH}_{3}$ and $\mathrm{CH}_{2}$ peaks and hence the presence of saturated hydrocarbons.

According to the porosity values obtained from the well logs (neutron and density logs), the Penek Formation sandstones have an average total porosity value of $18-25 \%$, and the Kömürlü Formation sandstones have an average total porosity value of $15-20 \%$. The clay percentage value evaluated using the gamma ray log was $59.4 \%$ for the Penek Formation and $58.4 \%$ for the Kömürlü Formation, which are high values.

This study aimed to assess the hydrocarbon potential of lithological units encountered during the drilling of a single well in the Aşkale sub-basin. To achieve the general objective, suites of wire-line logs from a single well were used for the analysis. Computed petrophysical parameters for two reservoir zones gave an average effective porosity ranging from 4 to $15 \%$ with a low permeability in the range of $0.00005-0.0002 \mathrm{mD}$. The low permeability indicates that the sandstone reservoirs are impermeable, which might have been caused by the high amount of clay minerals filling in open spaces, thereby reducing the permeability. The fluid type defined in the two sandstone reservoirs is basically water with high saturation greater than $88 \%$, which indicates that the proportion of void space occupied by water is high, and consequently, the hydrocarbon saturation and production are low. The low permeability, low porosity, abundant diagenetic minerals and high water saturation indicate that the reservoir quality of the studied prospect in the well is poor.

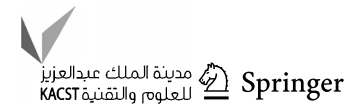


Fig. 16 a Depth-permeability cross-plot of Penek Formation. b Depth-porosity cross-plot of Penek Formation
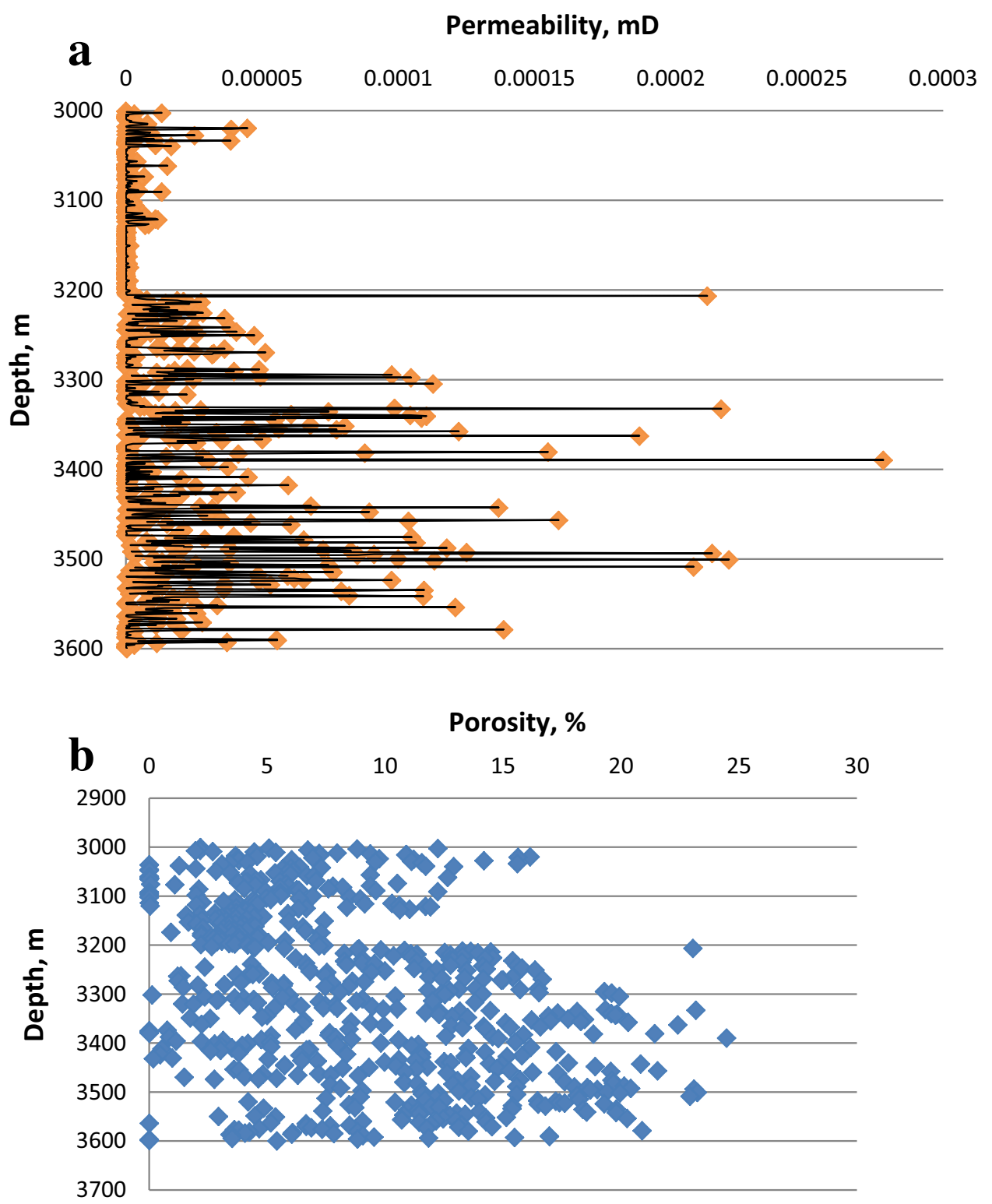

Table 4 The porosity and permeability values of Kömürlü Formation sandstones, Aşkale sub-basin

\begin{tabular}{lcl}
\hline Depth $(\mathrm{m})$ & Porosity $\%$ & $\begin{array}{l}\text { Perme- } \\
\text { ability } \\
(\mathrm{mD})\end{array}$ \\
\hline 2362.10 & 7.72 & 0.16 \\
2362.55 & 14.77 & 0.98 \\
2364.20 & 12.30 & 0.59 \\
2369.05 & 7.58 & 0.14 \\
2362.95 & 14.92 & 5.15 \\
2363.85 & 16.45 & 0.93 \\
2369.90 & 5.23 & 0.44 \\
\hline
\end{tabular}

Acknowledgements This study forms part of the master thesis of Fatih Gültekin, which is conducted in Ankara University by the supervision of Dr. Aynur BÜYÜKUTKU. Thesis was carried out by project signed between Turkish Petroleum Corporation and Ankara University in year 2009. The authors thank Turkish Petroleum Corporation very much for core and clastic samples, and single well logs.

Open Access This article is distributed under the terms of the Creative Commons Attribution 4.0 International License (http://creativeco mmons.org/licenses/by/4.0/), which permits unrestricted use, distribution, and reproduction in any medium, provided you give appropriate credit to the original author(s) and the source, provide a link to the Creative Commons license, and indicate if changes were made. 


\section{References}

Adamu MB (2010) Fourier transform infrared spectroscopic determination of shale minerals in reservoir rocks. Niger J Basic Appl Sci 18:6-18

Aksu R (1988) Tekman baseninde yeni bulgular ve öneriler. TPAO Arama Grubu Report number, 2047, Ankara (unpublished)

Alstadt KN, Katti DR, Katti KS (2012) An in situ FTIR step-scan photoacoustic investigation of kerogen and minerals in oil shale. Spectrochim Acta A Mol Biomol Spectrosc 89:105-113

Awaja F, Bhargava S (2006) The prediction of clay contents in oil shale using DRIFTS and TGA data facilitated by multivariate calibration. Fuel 85:1396-1402

Boles AB, Franks SG (1979) Clay diagenesis in Wilcox sandstones of southwest Texas, implications of smectite diagenesis on sandstone cementation. J Sed Petrol 49:55-70

Breen C, Clegg F, Herron MM, Hild GP, Hillier S, Hughes TL, Jones TGJ, Matteson A, Yarwood J (2008) Bulk mineralogical characterisation of oilfield reservoir rocks and sandstones using diffuse reflectance infrared Fourier transform spectroscopy and partial least squares analysis. J Petrol Sci Eng 60:1-17

Büyükutku AG (2002) Doğu Anadolu Havzalarında Yer Alan Üst Oligosen ve Miyo Pliyosen Yaşlı Kumtaşları ile Burdigaliyen-Langhiyen Yaşlı Resifal Kireçtaşlarının Hazne Kaya Özellikleri, TPAO Arama Grubu Report number, 4357, Ankara (unpublished)

Büyükutku GA, Şahintürk Ö (2005) The diagenesis of the Upper Oligocene and Mio-Pliocene Sandstones and its relevance to hydrocarbon exploration in the East Anatolia Basin, Turkey. Geol Soc India 65/4:468-478

Büyükutku GA, Şahintürk Ö (2006) The effect of ductile-lithic sand grains, overpressure and secondary dissolution on porosity and permeability and their relevance to hydrocarbon exploration in Aşkale Sub-Basin, East Anatolia, Turkey. Energy Sources, Part A: recovery. Util Environ Effects 28:1027-1038

Hartmann DJ (1989) Pore geometry and formation evaluation pay recognition-reservoir description. In: Michigan Basin Geological Society Continuing Education Seminar, p 46

Hassouta L, Buatier MD, Potdevin JL, Liewig N (1999) Clay diagenesis in the sandstone reservoir of The Ellon Field (Alwyn. North Sea). Clays Clay Miner 47:269-285

Herron MM, Loan M, Charsky AM, Herron SL, Pomerantz AE, Polyakov M (2014) Kerogen content and maturity, mineralogy and clay typing from DRIFTS analysis of cuttings or core. Petrophysics 55:435-446

İlker S (1966) Erzurum Bölgesinde Erzurum i47c1, c4, d2, d3 paftalarının detay petrol etüdü hakkında rapor, MTA Report number, 4236, Ankara (unpublished)

Kurtman F, Akkus MF (1971) Intermountain basins in eastern Anatolia and their oil possibilities. Bull Miner Res Explor Inst Turkey $77: 1-9$

Madejova J, Komadel P (2001) Baseline studies of the clay minerals society source clays: INFRARED methods. Clays Clay Miner 49:410-432

McBride EF (1963) A classification of common sandstones. J Sedim Petrol 33:667

McKenzie D (1976) The East Anatolian fault: a major structure in Eastern Turkey. Earth Planet Sci Lett 29:189-193

Nelson P (2009) Pore-throat sizes in sandstones, tight sandstones, and shales. AAPG Bull 3:93
Özkanlı M (1990) Log interpretation principles and application. Turk Petrol Corp 1990:1-273

Şahintürk Ö (1992) Tercan Çayırlı baseninin hidrokarbon olanakları, Çayırlı-Mercan-Tercan Kuzeyinde Yer Alan "Sakarya Tipi" Birimlerin Öz Olarak İrdelenmesi ve Öneriler. TPAO Arama Grubu Report number, 3070, Ankara (unpublished)

Şahintürk Ö, Kasar S (1980) Tercan-Çayırlı Baseninin jeolojisi ve hidrokarbon olanakları, TPAO Arama Grubu Report number, 1446, Ankara (unpublished)

Şahintürk Ö, Şaroğlu F, Çaptuğ A, Temel Ö, İlleez HI, Tekin T (1997) Ağrı yöresinin jeolojisi ve hidrokarbon olanakları. TPAO Arama Grubu Report number, 3790, Ankara (unpublished)

Şahintürk Ö, Şaroğlu F, Çaptuğ A (1998) Doğu Anadolu (Erzurum Kars-D.Beyazıt-Ağrı) jeoloji gezisi el kitabı, TPAO Arama Grubu Report number, 4172, Ankara (unpublished)

Schlumberger (1984) Log interpretation charts. Schlumberger Educational Services, Houston, pp 13-19

Schlumberger (1986) Log interpretation charts. Schlumberger Educational Services, Houston, pp 1-131

Schlumberger (1996) Log interpretation charts. Schlumberger Well Services, Houston, pp 2-34

Şengor AMC (1980) Fundamentals of neotectonics of Turkey. In: Conference Series 2, Ankara, Turkey

Shoval S, Nathan Y (2011) Analyzing the calcination of sulfur-rich calcareous oil shales using FT-IR spectroscopy and applying curvefitting technique. J Therm Anal Calorim 105:883-896

Sungurlu O (1971) İ45a, İ45b, İ46a, İ46b, İ47a, İ47b, paftalarına ait 1/50000 lik jeoloji haritaları, TPAO, Ankara (unpublished)

Tarhan N, Deveciler E, Karabalık NN, Akdogan E, Çolak T, Kar H (1992) Aşkale- Çat (Erzurum) dolayının jeolojisi. MTA Report number, 9447, Ankara (unpublished)

Tc Tchalenko J (1977) A reconnaissance of the seismicity and tectonics at the northern border of the Arabian Plate (Lake Van region). Rev Geol Dyn Geogr Phys XIX:189-208

Tekin T (2002) Source rock potential and organic facies properties of the Oligo-Miocene deposits in the Pasinler-Horasan, TercanAşkale basins (East Anatolia). The Graduate School of Natural and Applied Sciences of METU, Ph.D. thesis

Tekin T, Alişan C, Işık U, Akça N, Aras M, Günal B (2000) Aşkale-1 kuyusu sonuç raporu, TPAO Araştırma Grubu Report number, 2514, Ankara (unpublished)

Timur A (1968) An investigation of permeability, porosity, and residual water saturation relationships for sandstones reservoirs. Log Anal 9:3-5

Udvardi B, Kovacs IJ, Kónya P, Földvari M, Füri J, Budai F, Falus G, Fancsik T, Szabó C, Szalai Z, Mihály J (2014) Application of attenuated total reflectance Fourier transform infrared spectroscopy in the mineralogical study of a landslide area, Hungary. Sed Geol 313:1-14

Van der Marel HW, Beutelspacher H (1976) Atlas of infrared spectroscopy of clay minerals and their admixtures, 1st edn. Elsevier, Amsterdam, pp 241-248, 305-315

Whitney DL, Evans BW (2010) Abbreviations for names of rock-forming minerals. Am Miner 95:185-187

Publisher's Note Springer Nature remains neutral with regard to jurisdictional claims in published maps and institutional affiliations. 